\title{
MODAL LOGIC IN GERMANY AT THE BEGINNING OF THE SEVENTEENTH CENTURY: CHRISTOPH SCHEIBLER'S OPUS LOGICUM
}

\author{
Gino Roncaglia* \\ (Tuscia University, Viterbo, Italy)
}

\section{INTRODUCTION}

Despite the impressive work that has been done during the last decades in the field of the history of logic, our knowledge of the logical debate towards the end of the Middle Ages and in the Early Modern period is still fragmentary. There are a few prominent figures - Leibniz being probably the most important - whose logical works are relatively well known and widely studied. But even the most informed historian would surely admit his ignorance concerning the great majority of the many hundreds (actually, thousands) of logical textbooks published during the sixteenth and seventeenth centuries.

Some facts may help us to grasp the dimensions - and the complexity of the challenge that historians of logic are confronted with. Let us consider for a moment just the third decade of the seventeenth century, using Wilhelm Risse's Bibliographia logica (Risse 1965-1979). For the period 1620-1629, Risse has entries for 288 books published in the field of logic. Among the authors, some are relatively well known (Fonseca, Ramus, Toletus, Zabarella, Bacon, Gassendi...), but many of them would probably not ring a bell. Who are, to start with the very first and the very last entries for 1620, Johannes Albanus and Bernhardus Wyl? Who is the Edward Brerewood, who in 1628 published two different logical textbooks, one in Oxford and one in Frankfurt, and has 10 entries for the period 1614-1653?

For the period 1550-1650 Risse's research hints at quite a sustained output of books in the field of logic: about 20-30 titles published every year (and we know that Risse's list is still largely incomplete). The geographical distribution of these works is rather interesting, and - even considering that

\footnotetext{
*Unless otherwise noted, italics in the quotations are found in the original.
} 
any additions to Risse's list will most likely be books published outside the German speaking world - clearly shows the prominent role of German universities in the cultural output of the time. With reference to the period 1620-1630, and if my rapid calculations are correct, more books were published in Frankfurt (18 entries) than in Paris (17 entries), and more books were published in Cologne (17 entries) than in London (13 entries). More than 50 textbooks in logic (to be precise: 56) were published in the four cities of Frankfurt, Cologne, Wittenberg, and Helmstadt alone.

These numbers offer of course a merely quantitative (and furthermore incomplete) picture of the situation, but they should suffice to make it clear that the scholarly work awaiting historians of logic interested in this period is huge - and that a substantial part of it should take into account the logical works published in the German speaking world.

With regard to logic in the sixteenth and seventeenth centuries, we find ourselves today in a situation somewhat similar to that which characterized the history of medieval logic until a few decades ago. Attention has been focused on a limited number of authors, though the logical output is vast; consequently there is the risk of hasty value-laden judgements: of prematurely singling out a single author and his views as particularly significant or (the opposite extreme) of making sweeping generalizations. In this situation, one study can make an important contribution to our knowledge of certain authors or of specific thematic areas, but it cannot set out to provide a complete and definitive picture. That can only be achieved through sustained historical research into the period by a large number of historians, i.e. just what has occurred in the study of medieval logic in the last decades.

My objective here is to explore a limited, though extremely important and interesting, theoretical area - that of modal logic - with reference first and foremost to the German situation, and concentrating on the output of the universities during the first half of the seventeenth century. I have recently published a monograph on this subject in Italian, ${ }^{1}$ which gives a more indepth analysis of the historical and institutional context, the situation at the university, and the teaching practices that were the framework in which the authors I shall be dealing with here created their ideas. In that publication, I took as my starting point when studying the logical thought of the period the role of the copula, proceeding from there to the modal theories of four relatively little-known authors - Bartholdus Nihusius, Johannes a Felden, Johannes Weiss, Johannes Paulus Felwinger - who, between 1621 and 1664, wrote some texts specifically devoted to modal logic. ${ }^{2}$ Though there will be some overlapping with my previous work, here I wish to employ a

\footnotetext{
${ }^{1}$ Roncaglia 1996.

${ }^{2}$ Nihusius 1621; Felden 1642; Weiss 1653; Felwinger 1664.
} 
somewhat different perspective, by choosing to use as my main point of reference the section devoted to modality in a "general" logical handbook which was at the time particularly popular: Christoph Scheibler's Opus logicum. In this way I hope to give a more systematic (though perhaps less detailed) picture of the subject. I intend to use Scheibler's text as a point of reference; following its structure, however, will offer the opportunity to consider both the theoretical background to many of the problems analyzed, and the examination of these problems in other authors of the period.

I think that Scheibler's work is particularly well suited to serve as the focus for this study. For one thing, it is a text constructed systematically: it is no accident that Scheibler was known as the "German Suárez". ${ }^{3}$ Particular attention is thus paid to expositive clarity, and the text is rich in examples and explicit references to the positions of other authors. Moreover, it was a widely circulated and very influential work.

Christoph Scheibler was born in 1589 at Armsfeld (Nordhessen). ${ }^{4}$ After studying at Marburg and Giessen, Scheibler embarked on a brilliant career at Giessen University: first as professor of Greek (in 1610, at the age of only 21), then of Logic and Metaphysics; he became dean in 1615, and rector at the age of 27 in 1616. After temporarily suspending his university activity in 1624, Scheibler moved to Dortmund, ${ }^{5}$ serving as head of the local Gymnasium. In those years, right until his death in 1655, Scheibler also took part in theological disputes and controversies; in addition to his teaching, he gradually also became an important preacher. ${ }^{6}$

The Opus Logicum is actually a collection of four treatises, which had been published separately between 1613 and 1619: Introductio logicae (De natura logicae, praedicamentis, praedicabilibus, cum proemiali tractatu de philosophia), Topica (De argumentis, sive locis dialecticis), De propositionibus sive axiomatibus, De syllogismis et methodis.

In considering the general structure of the work, it should be immediately noted that Scheibler has chosen to place the treatment of the topics before the doctrine of the propositio. This choice is consciously defended at the beginning of the third treatise, ${ }^{7}$ and derives from the Scheibler's particular conception of the topics. In fact, in his opinion, the locus dialecticus or argumentum is a "terminus simplex vel notio logica, quae ad aliquid

\footnotetext{
${ }^{3}$ Cf. Risse 1964-1970, I, 470.

${ }^{4}$ On Scheibler, cf. Petersen 1920, 289 ff; Wundt 1939, 119-23; Eschweiler 1928, 294-95; Risse 1964-1970, I, 471-77; Lounela 1978, 66-71; Wollgast 1988, 187-89; Leinsle 1985, 32237 and 707-25; Pozzo 1989a, 20, 45-48, 96-98, 136.

${ }^{5}$ In Roncaglia 1996, 65 n. 39, an unfortunate lapsus calami resulted in Darmstadt instead of Dortmund as the town where Scheibler was head of the Gymnasium.

${ }^{6}$ For this information cf. in particular Leinsle 1985, 322-23 and Weber 1908, 7.

${ }^{7}$ The first section of the first chapter of this treatise is explicitly devoted to answering the question "An doctrina propositionum recte postponatur locis dialecticis" (Scheibler 1665, I, 390).
} 
arguendum affecta est" ${ }^{8}$ This conception is clearly connected with the fact that the standard example of an argumentum is the middle term of a syllogism, i.e. a simple term. The meaning of argumentum according to Scheibler is therefore quite different from the meaning usually given to the English term 'argument'. Given this view, if logic is to be presented from a synthetic point of view, the theory of the proposition should follow the discussion of topics: "Nam methodus synthetica progreditur a partibus ad totum". 9

It is also to be noted that Scheibler constantly uses axioma in the general sense of propositio. Despite the fact that this use indicates a Ramist influence $^{10}$ (and direct references to Ramus are in fact relatively frequent in Scheibler's work), it would definitely be wrong to classify Scheibler as a Ramist. Risse places him in the chapter devoted to systematic and Aristotelian authors, and notes on the one hand his eclecticism and on the other a certain dependence on the Paduan Averroists; all these features seem, in fact, to be present in his work to a certain extent.

Of the four treatises in the Opus logicum, the treatise that interests us most directly here is clearly the third one, which was first published (under the title Tractatus logicus de propositionibus sive axiomatibus) at Giessen in $1619,{ }^{11}$ and which consists of thirteen chapters. ${ }^{12}$ Let us take a quick look at the sections of the text:

I De axiomate in genere, eiusque partibus

II De divisione axiomatis in affirmatum \& negatum

III De propositione vera \& falsa

IV De propositione necessaria \& contingenti, possibili \& impossibili

V De propositione simplici \& composita

VI De propositione generali, particulari \& singulari

VII De propositione pura \& modali

VIII De aliis quibusdam divisionibus propositionum

IX De propositionum aequipollentia

$\mathrm{X}$ De conversione

XI De oppositione propositionum

XII De propositionum consecutione

XIII De regulis praedicandi

\footnotetext{
${ }^{8}$ Scheibler 1665, I, 143. Cf. also ibid.: "<Argumentum> ultimo sumitur pro omni termino, ex quo integratur \& essentialiter constituitur axioma. (...) Et in hac significatione nunc definitur argumentum."

${ }^{9}$ Scheibler 1665, I, 390.

${ }^{10}$ Cf. Nuchelmans 1980, 149ff.

${ }^{11}$ As regards the Opus Logicum as a whole, the first edition was printed at Marpurgi (Marburg) in 1634, whereas the one we shall refer to is the Francofurti (Frankfurt) 1665 edition, which is the first volume of the Opera philosophica.

${ }^{12}$ The table of contents on pp. 391-93 appears to indicate fourteen chapters, but in actual fact it jumps from the eleventh to the thirteenth (which in the body of the text is correctly labelled the twelfth).
} 
It will be noted that modal themes are dealt with both in the fourth and in the seventh chapters. What is the reason for this division of modal theories into two separate sections of the work?

The most immediate answer is that the division has its roots in a distinction between two general types of modal propositions: 1) absolute propositions that have been "modalized", i.e. classified modally - an example of this is the operation we carry out when we say that the proposition 'Homo est animal' is a necessary proposition; and 2) explicitly modal propositions, such as 'Necesse est hominem esse animal'. This distinction is rarely discussed, but it seems to play an important role in the way many authors of the period organized their treatment of modal issues. In the Opus logicum Scheibler does not refer to it explicitly, but it is briefly mentioned in his Opus metaphysicum:

Estque necessaria propositio, tum, quae pure talis est, ut homo est animal, tum, quae talis est modaliter, sive per expressum modum, ut Necesse est hominem esse animal. ${ }^{13}$

It is quite clear that Scheibler intends to deal with the first category in the fourth chapter, and the second category in the seventh chapter of the Opus logicum.

But this answer, though correct, does not sufficiently explain the reasons for (and the results of) dividing modal issues into two separate sections. In order to have a better understanding of this way of proceeding, it is necessary on the one hand to examine which theories are taken into account in each of the two chapters mentioned above, and, on the other, to consider the medieval and post-medieval tradition with regard to the order of the discussion of modal issues. We shall deal briefly with the latter point next.

\section{MODALITY: THE ORDER OF THE DISCUSSION}

In medieval logical texts, modal issues were usually introduced in the discussion of the properties of the propositio. We can take the first of Peter of Spain's twelve Tractatus (a collection that became very popular under the title Summulae Logicales) as indicative of the order of exposition generally followed. The definition and field of application of dialectica is given quite briefly at the beginning, and Peter of Spain describes this as "ars ad omnium methodorum principia viam habens". ${ }^{14}$ The place of application par excellence of the ars dialectica is the disputatio, which takes place mediante sermone. Sonus and vox are examined first, as the prerequisites of the sermo.

\footnotetext{
${ }^{13}$ Scheibler 1665, II, 165.

${ }^{14}$ Petrus Hispanus 1972, 1. The quotations that follow are taken from pp. 1-9 of the Tractatus.
} 
Next, Peter proceeds to the two basic types of vox significativa, noun and verb, providing the students with a link between the logical studies they were now engaged in and the grammatical studies they had already finished. Immediately after the discussion of the different kinds of vox significativa Peter defines oratio as "vox significativa ad placitum cuius partes significant separate", and propositio as an oratio "verum vel falsum significans". From here onwards, the rest of Peter of Spain's treatise is entirely devoted to the theory of the propositio. The first and most fundamental distinction advanced is that between categorical propositions and hypothetical propositions. "Cathegorica est illa que habet subiectum et predicatum principales partes sui, ut "homo currit'." "Propositio ypotetica est illa que habet duas propositiones cathegoricas principales partes sui, ut 'si homo currit, homo movetur'."

Categorical propositions are in their turn distinguished according to quantity (universal, particular, indefinite, singular) and quality (affirmative and negative). At this point the square of oppositions is introduced, along with a specification of which propositions are contrary, subcontrary, contradictory, and subaltern. Before introducing the laws that govern this square, the triplex materia categoricarum is discussed in a paragraph all to itself.

This is the first time we encounter modal issues, and this happens - in precisely the same way that we find in Scheibler - before the discussion specifically devoted to the propositio modalis, and in a context that focuses on categorical propositions. The passage goes as follows:

Propositionum triplex est materia, scilicet naturalis, contingens, et remota. Naturalis materia est, in qua predicatum est de esse subiecti vel proprium eius, ut homo est animal et homo est risibilis. Contingens materia est, in qua predicatum potest adesse vel abesse subiecto, ut homo est albus, homo non est albus. Remota materia est illa in qua predicatum non potest convenire cum subiecto, ut homo est asinus. ${ }^{15}$

Peter of Spain then uses these distinctions to determine which equivalences and oppositions are valid between propositions having the same terms but differing in quality and quantity. Hence, in the propositions in materia naturali what is attributed to one is attributed to all, and the universal is deducible from the singular and from the particular; similarly, in materia remota, what is removed from one is removed from all.

The basis of the differentiation between the three materiae propositionis - clearly grounded on strongly intensional considerations - seems to be the general idea of the distinction between essential propositions and accidental

\footnotetext{
${ }^{15}$ Ibid., 7.
} 
propositions ${ }^{16}$ the propositions in materia contingenti, in fact, express an accidental link between subject and predicate, a link that is therefore contingent in the sense that it is neither necessary nor impossible. Those in materia naturali express a necessity, i.e. they correspond to true essential propositions; those in materia remota express an impossibility, and correspond to false essential propositions. It is not surprising therefore that in his commentary on the De interpretatione, Thomas Aquinas speaks of materia necessaria vel naturalis and materia impossibilis sive remota. ${ }^{17}$

Klaus Jacobi notes with regard to Aquinas' distinction that the propositions in materia remota are seen to be analytically false, because they unite incompatible predicates. ${ }^{18}$ There is certainly also a strong link between modal and temporal issues, and in many later authors the presentation of the doctrine of the materia enunciationis is used as an opportunity to advance a "statistical" view of modality, in which the propositions in materia naturali (or necessary) are always true, those in materia contingens are sometimes true and sometimes false, those in materia remota (or impossible) are always false. ${ }^{19}$ It is possible, however, that precisely the focal issue in the doctrine of materia propositionis - the compatibility and coherence between predicate and subject - was one of the channels through which this statistical and temporal definition of modality was accompanied by a logical definition based on the principle of noncontradiction and on compatibility between subject and predicate.

In any event, what I am interested in emphasizing here is that the discussion of the triplex materia categoricarum concerns only categorical propositions, and therefore propositions not explicitly modalized. This is probably part of the background to Scheibler's division of modal topics into two separate sections. As in Scheibler, in Peter of Spain it is only later, after dealing with the rules about equipollences and conversions and after the discussion of hypothetical propositions (a category that traditionally included conditional, copulative, and disjunctive propositions), that the discussion of explicitly modal propositions occurs. This discussion is quite detailed, taking up about a third of Peter's first treatise.

In medieval and post-medieval scholastic texts, therefore, discussion of the propositio modalis normally comes after discussion of the distinction between the triplex materia categoricarum. This latter distinction shows a greater inclination towards intensional considerations, and - because of the

${ }^{16}$ Cf. Jacobi 1980, 63. The dichotomic root of the threefold division of the materia enuntiationis is quite clear in some of the very late commentaries on Peter of Spain. Cf. e.g. Dorbellus 1516, 9v-10v.

${ }^{17}$ Thoma de Aquino, In Periherm. I 1. 13.

${ }^{18}$ Jacobi 1980, 64.

${ }^{19}$ On the statistical conception of modality cf. Knuuttila 1993, and the literature referred to there. Further manifestations of the statistical view of modality in post-medieval logic are found in Knebel's contribution to this volume. 
frequent link with temporal issues (and concomitantly modal theories that are to a greater or lesser degree explicitly "statistical") - often shows signs of a conception of modality that is more "metaphysical" than "logical". One result, however, of the fact that issues of this type are given their own autonomous space is that, when the propositio modalis is dealt with in its own right, a more strictly "logical" attitude comes to the fore, in which modality appears as the explicit feature of the proposition and is not directly linked to an intensional and essentialist investigation of the terms which appear in it.

As regards the treatment of actual modal propositions, in Peter of Spain this opens with a discussion of what is meant by modus, which is followed by determining the number of modalizers, and then by an examination of the relations between modal propositions. This order is to be found in many later authors, often with the introduction, at some point in the discussion, of the distinction between modality de re and de dicto (or, in the terminology most frequently employed in the sixteenth and seventeenth centuries, between divided and compound modal propositions). ${ }^{20}$ In Peter of Spain this distinction appears as part of his treatment of the theory of the fallacies; but it has a pronounced role in the discussion of the propositio modalis in many medieval texts, and in particular in the influential treatise De modalibus traditionally attributed to Thomas Aquinas. ${ }^{21}$

It must not be thought, however, that the influence of medieval models strictly and invariably determines the order of the discussion of modal issues in sixteenth- and seventeenth-century "scholastic" authors. While there are certainly instances to be found of fundamental continuity between the medieval and post-medieval discussions - e.g., the Cursus of the Complutense College follows the expositive order of the De modalibus very closely - we sometimes find radical innovations. I will give some examples here.

When - as in Scheibler's case - we are concerned with general logical textbooks, not exclusively devoted to the discussion of modal issues, the problem of the order of the discussion arises on two levels: 1) where the modal section (or sections) is placed in the general plan of the work, and 2) how this section is organized internally. These two levels have a tendency to intersect. Thus, as has already been mentioned, the discussion of modal propositions is always introduced after the discussion of absolute or de inesse propositions. But whereas normally the presentation of the general characteristics of absolute propositions is directly followed by the discussion of their conversion, opposition, and equipollence, there are cases in which,

\footnotetext{
${ }^{20}$ On the relations between the two pairs of terms, cf. Roncaglia 1996, 93-94; Maierù 1972, 352, 380, 537 n. 136; Kretzmann 1981, 196 n. 8; Jacobi 1980, 199-200; Knuuttila 1993, 84-86.

${ }^{21}$ Cf. Roncaglia 1996, 98.
} 
in contrast, the general characteristics of the absolute proposition is immediately followed by the presentation of the propositio modalis, and this in turn is followed by the discussion of conversion, opposition, and equipollence, first between absolute propositions and then between modal propositions. $^{22}$

However, the idea - which is a traditional one - that the treatment of the specific nature of the propositio modalis must precede that of the interrelations between modal propositions (to which the discussion of conversion also pertains, since it deals with the relation between the proposition to be converted and the converted proposition) remains constant; normally the discussion of the quality and quantity of the modal proposition acts as a "bridge" between these two sections. The examination of modal syllogistics (which in some authors, e.g. Kesler, is extended to cover the broader concept of modal consequentiae ${ }^{23}$ ), on the other hand, always comes afterwards, in the section devoted to arguments, after the presentation of absolute syllogistics.

Though this "macrolevel" order of discussion remains fairly constant, the order within the section dealing specifically with the propositio modalis varies considerably. Depending on the author, the section may open with a defense of the usefulness of the doctrine ${ }^{24}$ though this sometimes appears at the end of the section (and this, as we shall see, is what Scheibler chooses to $\mathrm{do}^{25}$ ) or be omitted altogether; in other cases, the section opens with an examination of materia propositionis ${ }^{26}$ though this subject, in line with the medieval tradition, often appears before the section specifically dealing with propositio modalis ${ }^{27}$ another possibility, and this seems the most common choice, is for the section to open with the definition of modus and/or of propositio modalis. ${ }^{28}$

The differing ways various authors deal with the distinction - to which we shall return later - between compound and divided modal propositions are particularly interesting. Some authors consider it to be a fundamental element of the theory; for example the distinction is considered the first praesuppositio regarding the modal doctrine in Kesler's Tractatus de consequentia, ${ }^{29}$ and constitutes the first topic dealt with by Nihusius. ${ }^{30}$ By

\footnotetext{
${ }^{22}$ Cf. e.g. Scharfius $1652,120 \mathrm{ff}$.

${ }^{23}$ Cf. Kesler 1623, 55.

${ }^{24}$ Cf. e.g. (Cornelius) Martini 1623, 211; Felden 1642, 2-6.

${ }^{25}$ Cf. e.g. Scheibler 1665, I, 456.

${ }^{26}$ Cf. e.g. Mendoza 1618, 136-37; Ebel 1681, 102-103.

${ }^{27}$ Cf. e.g. Titelmannus 1545, 117v; Bartholinus 1628, 277 ff.; Collegii Complutensis disputationes, 16; Javellus 1629, 36v; Stahl 1656, 117-18.

${ }^{28}$ Cf. e.g. Titelmannus 1545, 123v; Horneius 1654, 78; Horneius 1633, 397; Scharfius 1652, 120; Scharfius 1632, 425.

${ }^{29}$ Kesler 1623, 55.

${ }^{30}$ Nihusius 1621, 10-19.
} 
contrast it is completely absent in other cases, e.g. in Horneius' Compendium dialectices (whereas in Horneius' longer Institutiones logicae the distinction is mentioned, but only in order to criticize it). ${ }^{31}$ Another topic that is particularly interesting in sixteenth- and seventeenth-century modal theories, the discussion of whether the mode pertains to the copula or to the predicate,$^{32}$ is given considerable space in some works, whereas it is absent in more introductory or more traditional textbooks. And the same could be said of the discussions of the relation between modal propositions and absolute propositions; of the nominal, verbal, or adverbial expression of the modes; or of the presentation of the rules of equipollence, conversion, and opposition between modal propositions. All of these are sometimes examined in great detail, ${ }^{33}$ sometimes limited to a rapid summary of the rules, ${ }^{34}$ and sometimes left out completely (particularly by authors who claim that modal propositions are not essentially different from absolute propositions, and that therefore ad hoc rules are not necessary). ${ }^{35}$

Of course, some of these differences may be explained by the fact that these texts differ in their aim, scope, and readership. But it should be clear from the above that this is not sufficient to explain the great variety of structure and content. Rather - and below I shall attempt to verify this thesis in Scheibler's case - I would suggest that the traditional scholastic "heritage" in the field of modality, though remaining an essential point of reference, underwent in the course of the following centuries a process of simultaneous enrichment and fragmentation, such that different portions of that heritage were concentrated on by different authors, and were often developed and extended to include problems and topics that originally had only been hinted at or were not found at all.

\section{MODALITY AND CATEGORICAL PROPOSITIONS}

Let us return to Scheibler. As we have seen, he deals with modal theories in two sections of the text: the fourth chapter entitled De propositione necessaria et contingenti, possibili \& impossibili, and the seventh chapter entitled De propositione pura et modali. The fifth chapter entitled De propositione simplici et composita, and the sixth, De propositione generali, particulari, \& singulari separate these two sections. It was suggested above

\footnotetext{
${ }^{31}$ Horneius 1654; Horneius 1633, 399-400.

${ }^{32}$ For a discussion of this topic, cf. Roncaglia 1996, 243-53.

${ }^{33}$ Cf. e.g. Scharfius $1632,428-35$.

${ }^{34}$ Cf. e.g. Ebel 1681, 109; (Jacobus) Martini 1612, 71.

${ }^{35}$ Cf. e.g. Rapp 1668; Dannhawer, as we shall see below at and around nn. 163-70, denied the distinction between compound and divided modal propositions as well as the division in kind between modal and absolute propositions.
} 
that the distinction between "modalized" absolute proposition and explicitly modal proposition presented an opportunity for authors to focus on different aspects of modal problems, stressing with the former metaphysical aspects and the intensional analysis of the terms and their essences, and with the latter the "logical" characteristics of the propositio modalis as a whole. As we shall see, an analytical reading of Scheibler's text permits us substantially to confirm this hypothesis.

Let us therefore begin to examine the theoretical content of the fourth chapter more closely. The first topic Scheibler deals with is the definition of what is meant by necessary, contingent, possible, and impossible propositions:

Propositio vera est necessaria vel contingens. Necessaria est, quae sic vera est, ut non possit esse falsa. Contingens est, quae sic vera est, ut possit esse falsa. (...) In oppositum, propositio falsa est vel possibilis vel impossibilis. Possibilis, quae sic falsa est, ut possit esse vera (...) Impossibilis, quae sic falsa est, ut nunquam possit esse vera $(. . .)^{36}$

It is worth examining some aspects of this definition more closely. First and foremost, the necessary, contingent, possible, and impossible modes are "projected" onto the division between true and false propositions. This "projection" occurs by following the scheme of the so-called "symmetrical" subdivision of modalities:

Table 1: "symmetrical" subdivision of modalities

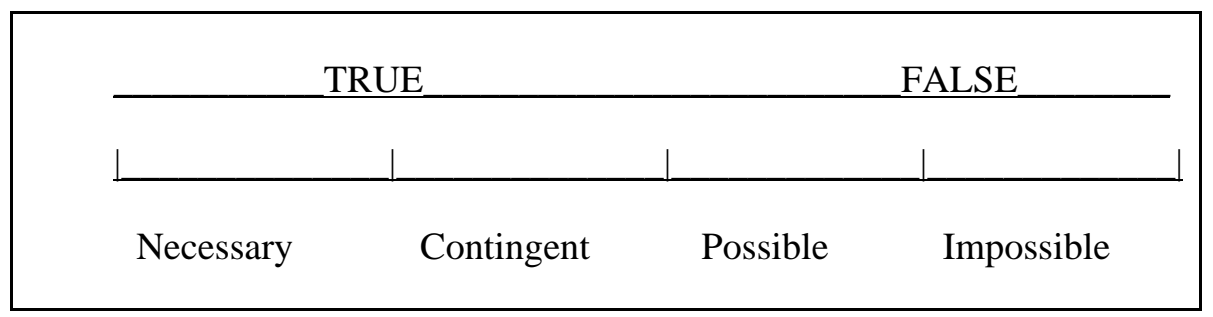

The division between true and false propositions would therefore seem to be considered an essential, most basic division from the logical point of view, and this seems to be confirmed by the fact that, as Scheibler has organized them, the immediately preceding chapter is De propositione vera et falsa. It is to be noted, however, that after formulating the above-mentioned definitions, Scheibler wonders "An divisio propositionis in necessariam \& contingentem conveniat propositioni in genere, ante omnem divisionem aliam, an vero sit divisio solum propositionis verae." The reply he gives is that "sine absurditate, in vocibus sistendo, necessarium $\&$ contingens posse

\footnotetext{
${ }^{36}$ Scheibler 1665, I, 408.
} 
dividere propositionem in genere, sicut \& impossibile \& possibile. ${ }^{37}$ In order to justify this position, Scheibler observes that a possible proposition can be considered to be contingently false, while a contingent proposition can be considered to be possibly false.

In order to get a better understanding of this argument, let us consider for example the possible proposition 'all men are walking'. This is the example normally used by Scheibler - it has a long history - of a proposition considered false (it seems quite implausible that at any given moment all existing men should be walking), but not impossible. Knowing that it is a possible (but false) proposition, we could obtain the contingent (true, but not necessary) proposition 'it is false that all men are walking'. On the other hand, a contingent proposition such as 'some men are walking' can lead us to the possible (false, but not impossible) proposition 'it is false that some men are walking'. Similarly, continues Scheibler, an impossible proposition can be considered to be necessarily false, and a necessary proposition to be impossibly false.

The idea, however, that the centrality of the alethic modalities (truth and falsity) is somehow attenuated by these considerations appears questionable. What Scheibler actually seems to be stressing is the existence, once the "symmetrical" subdivision of modalities has been assumed, of the following correspondences:

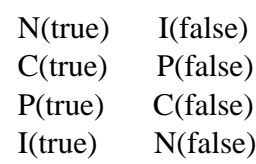

This might lead one to consider the particular equipollences that arise from a conception of this kind:

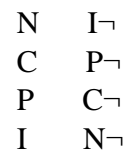

but does not seem to touch the fundamental role attributed to truth and falsity when defining modal concepts. In order to do that, it would be necessary to define what is true as what is necessary or contingent, and what is false as what is possible or impossible, and take the four traditional modal terms as prime concepts, leaving them undefined or defining them without resorting to alethic modalities: a position that Scheibler seems very far from advancing.

\footnotetext{
${ }^{37}$ Ibid.
} 
But let us return to the "symmetrical" subdivision of modalities represented by Table 1 . This is certainly not an original scheme, since it is already to be found in the Middle Ages. It is particularly interesting the way this division of modal concepts is introduced by the Summe Metenses, an anonymous treatise dating from the beginning of the thirteenth century and partially edited by L.M. de Rijk: ${ }^{38}$

Sciendum quod omnis inherentia predicati cum subiecto vel est et non potest non esse, et sic est necessaria (...), vel non est nec potest esse, et sic est inpossibilis (...), vel non est et potest esse, et sic est possibilis (...), vel est et potest $<$ non $>{ }^{39}$ esse, et sic est contingens. ${ }^{40}$

As can be seen, the number and reciprocal delimitation of modalities seem to a certain extent to be "deduced" combinatorially from the fundamental division between what is and what is not (which, transferred to the plane of propositions, corresponds to that between truth and falsity), further subdvided through the use of the verb potest. We get the clear impression that the passage quoted is not limited to recording correspondences, but intends to use them to justify both the number and the interrelations of the modal terms introduced. This kind of "deduction" of the number of modal terms and their reciprocal relations was quite common from the thirteenth century onwards, ${ }^{41}$ and (expressed in various ways) it is frequently found in the following centuries, up to the "scholastic" texts in German circles of the period that most concerns us here.

Sometimes the theoretical foundation of these late scholastic deductions seems to be the consideration of the potentia-actus dichotomy. This is the strategy chosen by Johannes Weiss: ${ }^{42}$

Quidquid enim dicitur esse, id vel actu esse dicitur, vel potentia. Si potentia, oritur inde modus possibilis; si vero actu, duplici id fit ratione: vel enim ita actu esse dicitur, ut aliter se habere non possit, \& sic est modus necessarius; vel ita actu esse dicitur ut aliter se habere possit, \& sic est modus contingens. Vel denique ita se habet aliquid, ut neque actu neque potentia esse dicatur, \& sic est modus impossibilis. ${ }^{43}$

This kind of theory seems to lead to the identification of the same group of four mutually exclusive and jointly exhaustive modalizers that we have found in Scheibler.

The position of another author, Martinus Caselius, who in 1633 presided over a Disputatio logica de modalium et exponibilium enunciationum natura et affectionibus, is quite similar, though he only refers to the actus and not to

\footnotetext{
${ }^{38}$ de Rijk 1962-1967, II-1, 452-90.

${ }^{39}$ For this convincing addition, not present in the text edited by de Rijk, cf. Jacobi 1980, 380 n. 36.

${ }^{40}$ de Rijk 1962-1967, vol. II-1, 467.

${ }^{41}$ Cf. e.g. Roger Bacon 1986, 250.

${ }^{42}$ On Weiss, cf. Roncaglia 1996, 63-65 and Schüling 1977.

${ }^{43}$ Weiss $1653,8$.
} 
the potentia, and he connects the number of modal terms to the modes of inherence (or convenientia, or respectus) between predicate and subject. Caselius also offers an ex auctoritate argument for the subdivision proposed:

Sufficere autem hunc quaternarium numerum probamus 1. Auctoritate Aristotelis c. 12 De Interpretatione par. 1; 2. Ratione, hoc modo: Quot modis variatur dispositionis qualitas, cum subjecto, si (...) respectus praedicati ad subiectum indicatur, tot etiam sunt modi, ut patet ex definitione modi. At quatuor modis hoc fit. (...) Quodlibet enim praedicatum (...) subjecto aut actu, aut non actu competit. Si actu, vel ita convenit, ut aliter se habere nequeat, scilicet non possit non inesse; vel ita idem tribuitur, ut possit non inesse. Si illud, necessario inest. Si hoc, praedicatum contingenter subjectum respicit. Si non actu convenit, vel per contradictionem illud, quod non est, nequit inesse, vel sine contradictione potest inesse. Si prius, praedicatum per impossibile subjectum respicit; si posterius, per possibile. ${ }^{44}$

Another author particularly concerned with modal topics, the abovementioned Bartholdus Nihusius, ${ }^{45}$ though not giving an explicit "deduction" of this type of modalizer, through the following observations on possibile and contingens gives us a glimpse of a basis for modal concepts similar to that seen above:

Contingens autem, ne nescias, proprie heic sumo, pro eo, quod quidem actu est, sed posse non esse. (...) De possibili enim accuratissime heic loquor, prout nempe dicit, rem actu non esse, sed saltem posse esse. ${ }^{46}$

Yet another argumentative strategy was used to defend a fourfold division of modal concepts similar to the one mentioned above. This strategy refers to the distinction between inherence and non-inherence, rather than to the distinction between potentia and actus. Nevertheless, from the point of view of the determination of the number of modalizers and their interrelations the results obtained are similar: the four modal terms become, in this case too, mutually exclusive and jointly exhaustive. The foundation of modality based on the different kinds of inherence and non-inherence of the predicate in the subject and its consequences in terms of the relations between the modal terms are explicit in another of the authors devoting a separate text to modal topics, Johannes Paulus Felwinger: ${ }^{47}$

Rejectis igitur reliquis modis, nostrorum modorum 4. sufficientiam probabimus tali modo: omne praedicatum vel dicitur subjecto inesse, vel non inesse. Si dicitur inesse, vel ita inest, ut non possit non inesse, \& sic nascitur modus necesse (...). Vel ita inest, ut possit non inesse, \& sic nascitur modus contingens (...). Si vero dicitur non inesse, vel ita non inest, ut nunquam possit inesse, \& sic nascitur modus impossibilis (...). Vel ita tandem non inest, ut tamen possit inesse, $\&$ sic nascitur modus possibilis. ${ }^{48}$

\footnotetext{
${ }^{44}$ Caselius 1633, sect. 1 par. 9.

${ }^{45}$ On Nihusius, cf. Roncaglia 1996, 55-60 and passim.

${ }^{46}$ Nihusius 1621, 15-16.

${ }^{47}$ On Felwinger, cf. Roncaglia 1996, 65-70 and passim.

${ }^{48}$ Felwinger 1664, 44-45.
} 
The deduction based on the distinction between truth and falsity that we found in Scheibler can be set alongside the deduction of modes through the kind of inherence or non-inherence of the predicate in the subject, since this is also a basis that pertains to some extent to the field of logic. It must be immediately noted, however, that later Scheibler himself seems to advance a different "foundation" of modes, based on the concepts of mutability and immutability. The result, however, remains the same:

Sicut enim necesse significat immutabilitatem in esse, et impossibile significat immutabilitatem in non esse, ita in oppositum contingens significat mutabilitatem in esse, et possibile mutabilitatem in non esse. Differunt ergo contingens \& possibile sic, quod contingens dicitur id, quod cum sit, potest tamen non esse; possibile autem, quod cum non sit, potest tamen esse. ${ }^{49}$

At this point we can note that the aim of these "deductions" often seems to be to show how logical modalities "refer" to some extent to the plane of metaphysical modalities. This procedure does not appear to be a reduction, but rather aims to show the original and essential characteristics of modal concepts, and therefore the need to deal with them. This search for a metaphysical foundation for modality can appear as a sort of retreat from a purely logical and formal discussion of the issue, and yet many authors, while defending the need for a distinction between the logical and the metaphysical investigation of modality, nevertheless do claim explicitly to proceed in a purely logical and formal fashion.$^{50}$ It seems difficult to deny that there is some tension here; and yet this tension must not be seen as being totally unresolvable. Metaphysical modalities constitute for the authors considered here - and for most of the western philosophical tradition - a fundamental feature of reality: it is not surprising therefore that it is also manifested in the field of logic, where propositions and their properties are "formally" dealt with. The recognition of this fact does not imply that, when considered from the logical point of view, modalities cannot be studied "formally", i.e. as properties of propositions that change their truth conditions and relations of interdeducibility. It is worth noting, however, that Scheibler chooses to place his "deduction" of the modal terms in the chapter De propositione necessaria et contingenti, possibili et impossibili, rather than in De propositione pura et modali, a choice that seems to confirm the tendency, mentioned above, to concentrate topics with more

${ }^{49}$ Scheibler 1665, I, 453 . The passage quoted is taken from chapter 7 , but the reference to mutability and immutability as the essential element in determining the nature of modal concepts - linked to but, as we shall see, not identical to the Boethian idea of a "mutable truth" which would characterize contingent propositions - also plays a fundamental role in Scheibler's chapter 4.

${ }^{50}$ Cf. Roncaglia 1996, 162-64. 
immediate metaphysical connections in the first section, and those more decidedly "formal" in the second.

The "symmetrical" treatment of modalities considered thus far is certainly not the only one derived from the medieval and post-medieval scholastic tradition. In fact, in part as a result of the different meanings Aristotle gives to the terms év6exácuon and 6uvoxóv, from late antiquity onwards at least three meanings of 'contingent' were widespread and another two meanings of 'possible', as is clear in the table below.

Table 2: Subdivisions of modalities in the period after the first Latin translations of Aristotle

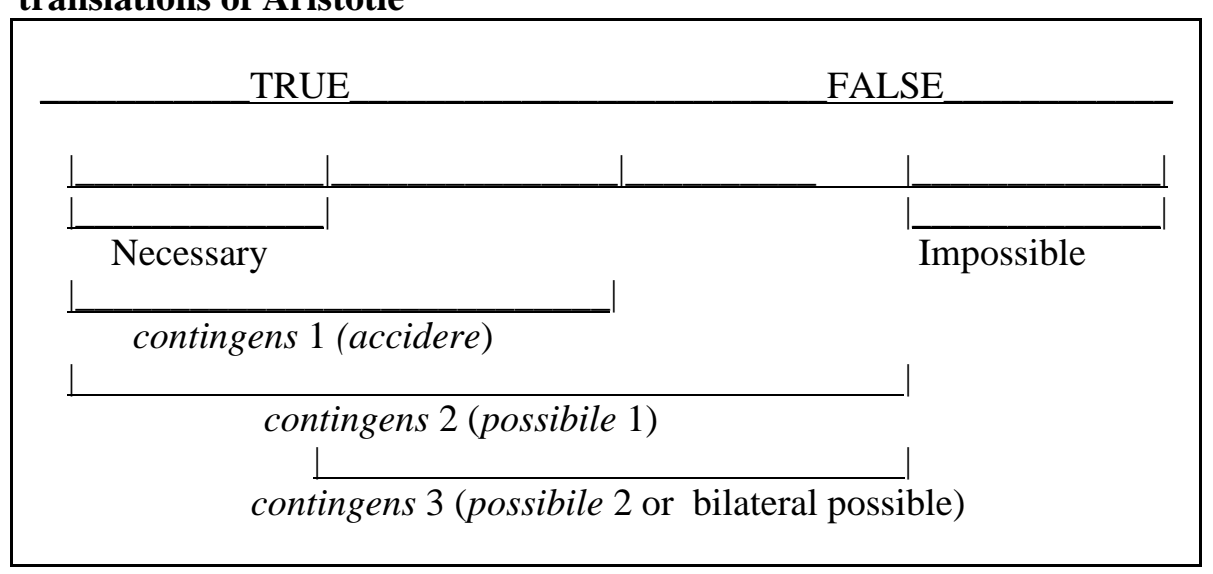

Like many other authors of the period, Scheibler himself mentions explicitly that 'possible' and 'contingent' can be considered synonyms:

Satis bene faciunt \& illi, qui propositionem dividunt in Necessariam, Contingentem \& Impossibilem. Ita enim possibilis coincidit cum contingente. ${ }^{52}$

Scheibler here is clearly discussing contingens 3 - possibile 2 in our table: an alternative conception to the symmetrical subdivision of modalities.

After this Scheibler dwells on the meaning of the term necessarium, observing that it can be understood in four different ways:

Nempe necessitas alia est in ratione causae, alia in ratione medii, alia in ratione Entis, alia in propositione. $^{53}$

\footnotetext{
${ }^{51}$ For a more detailed discussion of this table, cf. Roncaglia 1996, 73-77.

${ }^{52}$ Scheibler 1665, I, 408. Scheibler refers here, as his auctoritas, to Fonseca 1964, lib. III, cap. 5.

${ }^{53}$ Scheibler 1665, I, 408.
} 
In the first case it is necessary "quod agit vel ex necessitate naturae, vel ex coactione": it is a question of the necessity with which a natural or accidental cause produces its effects.

The second case occurs when "aliquid necessarium dicitur vel ad esse, vel ad bene esse". This is a category that seems to bring together the first

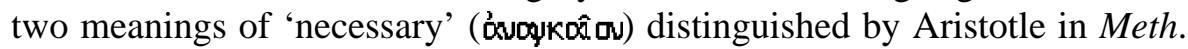
$\triangle, 5$ : what is necessary in order to sustain life, e.g. food and air, and what is necessary in order to maintain well-being, e.g. taking medicine to cure a disease. The connection between these two meanings seems to be the more general necessity of a means to a particular end. It is not surprising to find this category referred to, though of course not discussed, in a logical text. This type of necessity was not only recognized on the basis of Aristotelian authority, it also assumed a central position in interconfessional disputes in virtue of the highly disputed issue of whether good works are necessary in order to achieve the end represented by salvation.

The distinction between the third and fourth cases is particularly interesting. The necessitas entis - which, Scheibler informs us, coincides with the necessitas transcendentalis vel metaphysica as well as the necessitas incomplexa - is the one possessed by immutable beings. Really and truly this type of necessity pertains only to God, but it can also be spoken of with regard to universals, which, being universals, are immutable (mutability only concerns individuals). Scheibler also claims the necessitas propositionis (or necessitas complexa) has to do with immutability: what is immutable in this case, however, is the "connexio praedicati cum subiecto". 54

Even though Scheibler's treatment here is rather brief, ${ }^{55}$ this is a particularly interesting subject, connected with a fundamental question, the discussion of which is given by many authors as a "foreword" to the actual treatment of modal topics: does the treatment of modality belong in the field of logic? Shouldn't it rather be treated as part of metaphysics, given that necessity, contingency, possibility, and impossibility are affectiones entis?

This question was central also because Protestant metaphysics had developed to a high degree the doctrine of the affectiones entis, which involved discussions of Scotist origin on the Aristotelian theory of the categories as well as a reconsideration of the traditional list of transcendental terms. The affectiones entis were thus placed in a list that included terms such as unum, multa, actus, potentia, idem, diversum, aequale, inaequale, finitum, infinitum, possibile, necessarium, verum, falsum, ${ }^{56}$ and Daniel

\footnotetext{
${ }^{54}$ Ibid.

${ }^{55}$ The necessitas entis is the focus of attention in Scheibler's Opus metaphysicum I, 18 (Scheibler 1665, II, 164-76).

${ }^{56}$ The lists resulting from the discussion of the affectiones entis should perhaps be included among the sources of, amongst other authors of the period, Leibniz' attempts to
} 
Cramer, the man who reintroduced metaphysics into the Protestant world, had singled out their investigation as the prime task of metaphysics. ${ }^{57}$

The response generally offered to this question was that logic and metaphysics are concerned with modal concepts in different ways. In Felwinger's words, for example, in the field of metaphysics

considerantur necessitas, contingentia, possibilitas \& impossibilitas, quatenus sunt Entis affectiones, aut Entis quid repugnans, v.g. impossibilitas. Itemque considerantur, ut termini reales \& notiones primae. ${ }^{58}$

Logic, on the other hand, deals with a purely formal consideration of modal terms, insofar as they are present within a proposition.

Nevertheless, the question remained: precisely what formal function exercised by modal terms makes them pertinent to logic rather than to metaphysics? To this question different answers were given depending on the particular theory of modality advocated. According to Felwinger, in contrast to what is the case in metaphysics, in logic the modal terms are considered

quatenus sunt determinationes copulae, $\&$ respectu praedicati ad subjectum, quatenus scilicet ostendunt peculiarem compositionis modum in enunciationibus. ${ }^{59}$

Caselius holds a similar position: modalities

in metaphysica considerantur, quatenus sunt termini reales \& notiones primae; in logica vero quatenus sunt determinationes copulae. ${ }^{60}$

One should remember that the distinction between "metaphysical" discussions and "logical" discussions of modality often involves a tacit reference to the section devoted to modal topics in the Erotemata dialectices by Melanchthon, who, alongside a concise discussion of some of the traditional topics connected with the propositio modalis, deals with problems normally considered at the time to be in the province of metaphysics rather than logic, such as the discussion of future contingents and of different kinds of necessity. ${ }^{61}$ The (somewhat) inappropriate place assigned to these discussions in Melanchthon's text was to be pointed out by Kornelius Martini, who justifies it only by reason of expository convenience, emphasizing that logic should concern itself solely with the

distinguish a small group of primitive terms. To my knowledge this is a connection that is still to be explored. As regards the metaphysical importance of the discussion on the affectiones entis, interesting observations are to be found in Leinsle 1985, passim.

${ }^{57}$ Cf. Leinsle 1985, 167-69.

${ }^{58}$ Felwinger 1664, 6.

${ }^{59}$ Felwinger 1664, 6 .

${ }^{60}$ Caselius 1633, sect. 1 par. 14.

${ }^{61}$ Melanchthon 1846, coll. 588-94. 
formal aspects of the application of modalities to propositions: logic is in fact an instrumental discipline, "non igitur res ipsas tractare potest. At Contingentia \& Necessitas res sunt, non Instrumenta". ${ }^{62}$ Scheibler, however, seems to have a very different point of view: Melanchthon's treatment is not directly cited - for example, Scheibler shows no cognizance of the fourfold division into absolute necessity, logical necessity, physical necessity and hypothetical necessity which is one of the most interesting features of the discussion of modal topics in the Erotemata - but in this fourth chapter Scheibler's treatment of the concepts of necessity and contingency leads to considerations of definite metaphysical importance.

Once the distinction between necessitas entis and necessitas propositionis has been introduced, however, Scheibler does not dwell on it, stressing merely that he will refer to this last type of necessity in the text. Though this seems quite natural - this is after all a logical text - it must be noted that claiming a form of immutability (that of the connexio between subject and predicate) to be the feature characteristic of the necessitas propositionis introduces into the sphere of logic some features usually pertinent to the metaphysical treatment of the necessitas entis. This impression is reinforced by the discussion that immediately follows these passages, and that refers to the traditional distinction between necessitas absoluta and necessitas ex hypothesi: the first is for all intents and purposes characterized by Scheibler through immutability, since he claims that it pertains to a proposition "quae habet immutabilem veritatem".

Immediately afterwards Scheibler notes that the necessitas propositionis is broader than the necessitas demonstrativa. The latter, in effect, should always have to do with affirmative universal propositions (de omni), whereas particular or negative propositions may also belong to the former. This observation permits him to move on from the discussion of necessitas propositionis in general to the necessity that is particular to the de omni propositions, and therefore to themes traditionally connected with Aristotle's Posterior Analytics. In opposition to Dounamus, ${ }^{63}$ Scheibler insists that only universal propositions can be de omni in the Aristotelian sense. The universality required is not only that of the subject, but also that of time: a de omni proposition must in fact be always true.

Scheibler's discussion of de omni and per se necessity (which includes a detailed analysis of the two modi dicendi per se) goes on for twenty-two closely written columns of text. Moreover, it is followed by a further eleven columns of analysis of the Aristotelian axioma catholicum: these are topics in which Scheibler is doubtless influenced by his reading of Zabarella, and in the context of the present discussion it would be interesting to examine

\footnotetext{
${ }^{62}$ (Cornelius) Martini 1623, 234-35.

${ }^{63}$ On Dounamus, cf. Risse 1964-1970, I, 171.
} 
them also on the relation Scheibler holds there to be between necessity and analyticity, but this would take us too far from the specific field that concerns us here.

This discussion of necessity is followed by a discussion of contingency. As we shall see, in this case too Scheibler's considerations span logic and metaphysics. The first example of this is the very definition of contingency:

Contingentia proxime significat mutabilitatem. Indeque contingentia in essendo est, secundum quam Ens est mutabile intra esse, \& non esse, veluti, cum quod est, potest tamen non esse. Eadem ergo ratione etiam propositio contingens dicitur, ratione mutabilitatis alicuius, non quidem, quae sit in essendo, sed quae sit ratione veritatis illius. Nempe propositio contingens hactenus est ista, quae veritatem habet mutabilem. ${ }^{64}$

Clearly, the relation between the definition of propositio contingens and that of contingentia in essendo is even closer and more explicit than that between the definitions of necessitas propositionis and necessitas entis. Attention must be paid to the fact that the connection, of Boethian origin, between contingency and mutable truth is not to be interpreted in the sense that there are true contingent propositions and false contingent propositions: the characteristic of "mutability" attributed to the truth of contingent propositions presupposes that they are true, though true in such a way that they might also be false. This view might suggest an interpretation in terms of counterfactual possibilities in alternative possible worlds. And one might be tempted to seek confirmation of this hypothesis in the following passage, in which it is very clearly specified that the possible falseness of a contingent proposition is not relative to future time - in fact, it is not relative to any differentia temporis: ${ }^{65}$

Definitur propositio contingens sic, quod sit ea, quae sic vera est, ut possit esse falsa. Illud tamen possit, non est intelligendum per ordinem ad tempus futurum, quasi scilicet ea tantum sit propositio contingens, quae deinceps \& quasi futuro tempore possit secus esse, sed intelligitur illa particula indifferenter ad quodvis tempus, prout verba in definitionibus exigunt. Et proinde dantur propositiones contingentes, secundum omnis temporis differentias. De praesenti (...), de futuro (..), de praeterito (...). ${ }^{66}$

The possibility of doing completely without temporal notions seems clearly envisioned in a passage immediately following the text just quoted. Scheibler says:

\footnotetext{
${ }^{64}$ Scheibler 1665, I, 425

${ }^{65}$ Note that the concept of differentia temporis is traditionally connected to the doctrine of ampliatio, and that in the late medieval period the modal concepts were often included, together with past, present, and future, in the list of differentiae temporis: cf. Roncaglia 1996, 179 and the literature referred to there.

${ }^{66}$ Scheibler 1665, I, 425.
} 
Unde consequenter generaliter \& in indifferentia loquendo, contingens propositio dicetur omnis illa, cuius extrema talia sunt, ut non postulent necessario coniuncta esse, sed, prescindendo a connotatione temporis, talia sunt, quae vel cohaereant, vel non cohaereant. ${ }^{67}$

There are, however, serious obstacles to interpreting Scheibler in this way. It must first be remembered that, before this passage, through repeatedly characterizing necessity as immutability and defining contingency in terms of mutability, Scheibler seemed to have built up such a close relation between modal considerations and temporal considerations that the resulting conception of modality seems to be at least partially statistical. Doubtless the acceptance of contingent propositions "secundum omnis temporis differentias" seems to support a different reading, but what then is the relation between the two approaches, which seem to be mutually exclusive?

What we have seen so far leaves the impression that Scheibler believes it possible to furnish both an explanation that we might call "temporal" in terms of mutability and immutability, and an explanation that we might call "logical" in terms of agreement or non-agreement between terms. Apparently Scheibler conceives these two approaches not only not to be contradictory, but convergent. Thus, in discussing the example of the contingent proposition Johannes disputat (with its variations Johannes disputabit and Johannes disputavit), he goes on to observe:

Ita nempe in superioribus propositionibus termini sunt: Johannes \& Disputatio. Hi termini contingenter cohaerent, quia Johannes manebit Johannes si maxime non coniungatur ei actus disputandi, quocunque tandem in tempore sit: aut, quia si aliquo tempore cum eo iste actus coniungatur, alio non coniungatur. Haec enim omnia indicant mutabilitatem connexionis illius. ${ }^{68}$

I think this passage is particularly significant for grasping Scheibler's conception of modal terms: in fact both a terminology normally associated with a conception of modality whose central element is the type of agreement between subject and predicate, and an openly temporal conception converge here. The "common ground" on which this convergence takes place is a fundamentally essentialist view of modal concepts: a view according to which necessity has to do with essential (and therefore omni-temporal) predication, and contingency with accidental predication. This is expressed in the passage by the statement "Johannes manebit Johannes si maxime non coniungatur ei actus disputandi": the attribution or non-attribution to John of the property of disputing does not change his essence.

\footnotetext{
${ }^{67}$ Ibid.; the italics are mine.

${ }^{68}$ Ibid.
} 
Clearly, these different conceptions of modal terms might be divergent: for example, a certain property might be attributed to John in every time without it being an essential property. Scheibler, however, does not seem at all aware of this kind of problem: in the passages we have examined, the essential properties are obviously identified with those that are not subject to temporal changes. And even the extremely stimulating problem of the essential identity of an individual (John) is merely hinted at, and developed no further. Later, Scheibler dwells on the traditional distinction - deriving from Aristotle and obviously connected to a basically temporal and statistical conception of modality - between contingent ut in paucioribus, contingent ut in pluribus, and contingent ad utrumlibet. ${ }^{69}$

There follows a discussion of a number of quaestiones, some of theological interest (whether propositions expressing a free act of God, such as Deus creat mundum, are contingent or not: the answer is - as could be foreseen - affirmative), others once again connected with the relation between modality and temporality (whether present tense and past tense propositions can be contingent or not). It is to be noted that many of the issues dealt with by Scheibler in this context are similar to those discussed by Melanchthon in the above-mentioned section of the Erotemata devoted to modality. ${ }^{70}$ Among the possible arguments Scheibler puts forward in favour of a negative reply to the question "An propositiones de praesenti sint contingentes" is, in a fully traditional way, the Aristotelian maxim whereby (in the formulation used here) "unumquodque dum est, necesse est esse". But the reply chosen by Scheibler is naturally the affirmative one. The justification adopted is based - again in a traditional manner ${ }^{71}-$ on the idea that in the case of a present tense contingent proposition the contingent act is accompanied by the power not to perform it:

Id enim vocatur contingens, quod ita est, ut possit non esse. Dico: possit non esse. Nam contingentia non copulat esse \& non esse ad idem actualiter. Haec enim esset contradictio manifesta. Sed copulat tò esse, potentiam ad non esse. Et ad non esse, copulat potentia ad essendum. Ergo sic contingens dicitur, quod dum est, potest non esse, et cum non est, potest tamen in proxime sequenti instanti esse. ${ }^{72}$

${ }^{69}$ In Analytica priora A 13, 32b 4-23, Aristotle distinguishes two meanings of the bilateral possible (the one referred to as contingens 3 in Table 2), which were to become in the medieval Latin tradition the ut in pluribus contingent and the infinite or indeterminate ( $a d$ utrumlibet) contingent. The first case includes events which, though devoid of necessity, are involved in the "natural course" of events (quod natum est esse); the second includes events that are totally indeterminate as regards their being and not being, such as "animal ambulare". The contingent ut in paucioribus is a natural "inversion" of the contingent $u t$ in pluribus, which is also well documented in the medieval tradition.

${ }^{70}$ Cf. Melanchthon 1846, coll. 588-94 and cf. above at and around n. 61.

${ }^{71}$ Cf. e.g. Suárez 1597, disp. XIX sect. 9.

${ }^{72}$ Scheibler 1665, I, 426. The term 'contingens' is used here in the sense of contingens 3 possibile 2 of Table 2 . 
Clearly Scheibler does not seem to allow an interpretation of contingency that relies on counterfactual possibility (the concluding observation "in proxime sequenti instanti" seems explicitly to bar this): ${ }^{73}$ his conception seems to be fundamentally essentialist and, once again, strongly influenced by temporal considerations.

At this point, even the defense of the view that might most easily open the way to the conscious consideration of counterfactual possibilities - that of the existence of contingent propositions in the past tense - will obviously be interpreted in the light of the context outlined above. We find in the discussion of the traditional example Paris rapuit Helenam (which Melanchthon also examines in some detail) and of the more curious "academic" example Ludovicus Landgravius Hassiae fundavit Academiam Gissenam (remember that the first version of the text dates from when Scheibler was teaching at Giessen), the statement according to which

Contingentes sunt tales propositiones, quia Paris potuit non rapere, \& Landgravius potuit non fundare Academiam. ${ }^{74}$

But what is implied by this passage is not the defense of counterfactual possibilities; rather, it is the evaluation as non-essential of the connection between Paris and Helen's abduction and between the Landgravius and the founding of an academy.

Then Scheibler draws a distinction concerning the contingency or lack of contingency of a proposition on the basis of the proposition being determinately true or false. What is at stake here is the eminently theological problem of divine foreknowledge, which leads Scheibler and most of his contemporaries to claim that also contingent propositions in the future tense are determinately true or false without losing their contingency. This is because the determinate nature of divine foreknowledge guarantees the possibility of attributing truth or falsity to them, while, as we have seen, their contingency depends rather on an evaluation of the essentialist type.

This discussion of necessity and contingency is followed by quite a brief discussion of possibility and impossibility. In the case of impossibility Scheibler's approach seems very much more markedly logical and based on the principle of non-contradiction:

Illa propositio nunc dicitur impossibilis, quae includit extremorum repugnantiam, quaeque adeo sic falsa est, ut nunquam \& nusquam possit esse vera. Veluti: Homo est lapis (...). Maxime autem impossibilia sunt, quae sunt ex terminis contradictoriis, veluti, albedo est non albedo (...). Quanquam \& in prioribus exemplis fundamentum impossibilitatis est in

${ }^{73}$ The observation that follows in the text, according to which "non sunt contradicentia, esse \& posse non esse", should therefore not be interpreted by attributing to Scheibler the acceptance of counterfactual possibilities, but as an alternative formulation of the abovementioned traditional conception.

${ }^{74}$ Scheibler 1665, I, 426. 
contradictione extremorum. Nempe impossibile est hominem esse lapidem, quia sic homo esset non homo, quia esset quid irrationale, \& lapis esset non lapis, quia esset rationalis. Unde impossibile in communi definitur ex repugnantia contradictoria, ut scilicet illud dicatur impossibile, quod involvit contradictionem. ${ }^{75}$

In this case too, Scheibler resorts to a traditional terminology, connected with the scholastic discussion concerning different kinds of oppositio. The use of the term repugnantia derives from this semantic sphere. ${ }^{76} \mathrm{We}$ have thus also explicitly encountered in Scheibler the conception of modality that resorts to the "logical" evaluation of the existence or non-existence of contradictions within the intension of the terms that appear in the proposition. This conception, however, seems to recede into the background a few lines later, when as regards possibility it is claimed:

Porro possibile denominatur a potentia. Possibile igitur hactenus est, quod subiacet alicuius potentiae. Ita cum Johannes non sit doctus, est tamen possibile eum esse doctum. Sunt enim causae in natura, quae possent Johannem reddere doctum. ${ }^{77}$

In concluding our examination of the modal issues Scheibler deals with in the fourth chapter of the treatise, some general observations must be made. First and foremost, it should be noted that he resorts to different conceptions of modality, based on mutability and immutability, on the agreement between terms, on the "metaphysical" distinction between potentia and actus, or (and this plays a particularly important role) on the distinction between essential and non-essential properties. These conceptions appear to be present simultaneously and often confusedly, and Scheibler seems to have little awareness of their potential incompatibility. However, underpinning Scheibler's position is the idea that understanding modal concepts requires a unitary conception, in which modality goes back to the metaphysical consideration of essences rather than to strictly logical considerations. Even repugnantia being used as a criterion of impossibility should be seen from this viewpoint: this is an evaluation that does not pertain to the plane of terms but to that of essences. And it is important to note in this regard how in the Opus metaphysicum - following Suárez closely $^{78}$ - Scheibler considers non-contradictoriness as one of the four distinctive features of the essence:

\footnotetext{
${ }^{75}$ Scheibler 1665, I, 428.

${ }^{76}$ Cf. Roncaglia 1990, and for more on oppositio and repugnantia see Mondadori's contribution to this volume.

${ }^{77}$ Ibid.

${ }^{78}$ Suárez 1597, disp. II, sect. 4, 7: "Quid autem sit essentiam esse realem, possumus aut per negationem, aut per affirmationem exponere. Priori modo dicimus essentiam realem esse, quae in sese nullam involvit repugnantiam."
} 
Quarto declaratur essentia per negationem. Et sic essentia est ille actus, qui non involvit repugnantiam, atque sic Ens dicitur omne illud, quod non involvit repugnantiam. ${ }^{79}$

\section{MODAL PROPOSITIONS}

Now we come to the second chapter that Scheibler devoted to modal issues, the seventh chapter of the Opus logicum. The chapter opens with the distinction between a pure proposition (that in which "praedicatum subiecto convenit simpliciter absque modo") and a modal proposition ("quae determinatur modo aliquo"). The latter is further divided into the primario dicta modal proposition, in which the mode that operates the determination is one of the four usual modal terms (necessary, possible, impossible, contingent), and the secundario dicta modal proposition, in which the determinative function is performed by an exclusive term (such as tantum, solum...), an exceptive term (such as praeter...), or a limitative term (the class that includes the so-called reduplicative constructs: "homo qua homo est risibilis"). What is meant by a pure proposition is clarified in Title I:

(...) Purum axioma est, quod habet ea, quae ad esse axiomatis pertinent, \& praeterea nihil alieni exigit. Porro ad esse axiomatis pertinet subiectum, praedicatum \& copula. Quod igitur haec habet, \& nihil aliud praeterea postulat, hoc est axioma purum, ut homo est animal. ${ }^{80}$

If this is the strict definition of a pure proposition, Scheibler nevertheless realizes that using it - without watering it down - in order to distinguish pure propositions from modal propositions would have the effect of including among modal propositions all propositions in which the rigid subject-copula-predicate structure is lacking for any reason, ${ }^{81}$ e.g. propositions that contain a quantifier or an adjective or an adverb.

This is a classic problem: it appears that even adjectives, adverbs, and some syncategorematic terms such as quantifiers have the capacity to "modify" a proposition: is this sufficient to render that proposition modal?

Let us consider the medieval tradition for a moment. With respect to adverbs and adjectives, the question was examined in the following way by Peter of Spain, when he gave his definition of modus:

Modus est adiacens rei determinatio. Et habet fieri per adiectivum. Sed quia adiectivum est duplex: est enim quoddam adiectivum nominis, ut albus et niger et consimilia, aliud autem verbi, ut adverbium; secundum enim Priscianum adverbium est ut verbi adiectivum - et ideo

${ }^{79}$ Scheibler 1665, II, 41.

${ }^{80}$ Scheibler 1665, I, 451.

${ }^{81}$ On the inclusion of the copula as a fundamental element of the proposition (thus seen as an essentially three-part structure), and on the conflict between this conception and the essentially two-part one which considers only the subject and predicate as the fundamental components of a proposition, cf. Roncaglia 1996, 107-48. 
duplex est modus: unus nominalis, qui fit per adiectiva nominis, alius adverbialis, qui fit per adiectiva adverbia, ut homo albus currit velociter. Item, adverbiorum quedam determinant verbum gratia compositionis, ut hec sex: necessario, contingenter, possibiliter, impossibiliter, vero et falso, alia determinant verbum ratione temporis, ut adverbia temporalia, alia ratione modi, ut adverbia optandi et hortandi, et ita de aliis. Et secundum hoc sumitur modus multiplex per adverbia. ${ }^{82}$

Let us examine the distinctions introduced by Peter of Spain more closely. The first, present in embryo in Boethius, ${ }^{83}$ concerns the difference between nominal modes, brought about by an adjective being added to the noun, and adverbial modes, brought about by adding an adverb to the verb. This is a distinction that we will encounter often and that sometimes plays an extremely significant role in subsequent authors. A parallel between these two cases - which Scheibler, as we shall see, deals with together by resorting to the category of material modes - is introduced by Peter of Spain with reference to Priscianus' Institutiones grammaticae, according to which the adverb functions as the "adjective" of the verb. ${ }^{84}$

Peter of Spain further distinguishes several different adverbial modes. Some regard temporal or qualitative or exhortative or optative modifications of the verb. Others - note the presence in this category of truth and falsity, in addition to the four traditional modes - determine the verb gratia compositionis. The explanation of what is meant by this determinatio compositionis is given in the following paragraph:

Sed omissis omnibus aliis de illo modo qui compositionem determinat, dicendum est, ut sunt isti sex: necessario, contingenter, etc. Cum enim dicitur homo necessario currit, significatur quod ista compositio sit necessaria. Cum autem dicitur homo currit bene vel velociter, significatur quod cursus hominis sit bonus vel velox. Et ita in ista determinatur res verbi, in prima vero compositio. Et sic intelligendum est de aliis predictis adverbiis. Unde solum ille modus qui determinat compositionem, facit propositionem modalem, et solum de tali hic intendimus. ${ }^{85}$

The differentiation between the different kinds of adverbial modes put forward in the previous paragraph thus shows a dichotomous structure: on the one hand, there are the modes through which determinatur res verbi, in other words, we might say, those that specifically affect the semantic content of the verb; on the other hand, there are those through which determinatur compositio. Only the latter constitute modal propositions, and therefore have specific logical relevance here. They are those that various authors describe as modes specialiter or stricte. Through this type of adverbial mode it is not the semantic content of the verb that is modified, but the way in which the

\footnotetext{
${ }^{82}$ Petrus Hispanus 1972, 11-12. On the history of the definition of modus cf. also Maierù 1972, 323-91 and Jacobi 1980, 66-132.

${ }^{83} \mathrm{Cf}$. Boethius 1880, 377, on whom cf. Maierù 1972, 328-32 (particularly 331).

${ }^{84}$ Priscianus 1885-1889, II 16, 54.

${ }^{85}$ Petrus Hispanus 1972, 12.
} 
verb performs its function as predicate. It is not surprising therefore that even in the Middle Ages most authors preferred the idea that what is modified in the modal proposition is the way the subject and predicate are connected, rather than the predicate itself. In this case the determinatio compositionis introduced by the strictly modal terms is seen not as an adverbial modification of the verb, but as a modification of the subjectpredicate relation. Thus, while in Peter of Spain the modes stricte seem to belong to the class of adverbs, many other authors tend to differentiate them from both adjectives and adverbs, on the basis that they neither modify the subject as subject, nor the predicate as predicate, but the relation between the two, the propositional compositio.

An example of this conception can be found in the De modalibus traditionally attributed to Thomas Aquinas:

Est autem modus determinatio rei, que quidem fit per adiectivum nomen quod determinat substantivum, ut cum dicitur homo albus; vel per adverbium quod determinat verbum, ut cum dicitur Sortes currit bene. Sciendum est igitur quod triplex est modus: quidam qui determinat subiectum propositionis, ut cum dicitur homo albus currit; quidam qui determinat predicatum, ut cum dicitur Sortes est homo albus vel Sortes currit velociter; quidam qui determinat compositionem ipsam predicati ad subiectum, ut cum dicitur Sortem currere est possibile; et ab hoc solo modo dicitur propositio modalis. ${ }^{86}$

At first the De modalibus seems to propose here the classic twofold division between adverbial modes and nominal modes, but then it clearly opts for a threefold division, in which the determinatio compositionis has a place all to itself. This was the path chosen by various logical writers in the twelfth and thirteenth centuries, for example the author of the Ars Meliduna ("Modalis est illa propositio qua modificatur coherentia predicati ad subiectum"). ${ }^{87}$

In the centuries that followed a general distinction between a broad or improper meaning of modality, which normally included at least adverbs and adjectives, and a narrow or proper meaning that included only the four traditional modal terms, remained widespread ${ }^{88}$ despite the fact that the "improper" modal terms taken into consideration might vary considerably from author to author. Let us examine the strategy adopted by Scheibler in this regard, and then compare it with the choices of other German authors of the period.

Scheibler's first concern is to exclude quantified propositions from his list of modal propositions. He maintains that, when distinguishing pure propositions from modal ones, when we give the above-mentioned

${ }^{86}$ Thoma de Aquino 1976, 421.

${ }^{87}$ de Rijk 1962-1967, II-1, 332.

${ }^{88}$ To give a few examples, we find it in the period that concerns us here in the Enchiridion logicum by Caspar Bartholinus (1628), 283-84; in the Palaestra rationis by Johannes Paulus Felwinger (1664), 36-38; and in the Quadriga disputationum logicarum by Johannes Weiss (1653), 6-7. 
definition of a pure proposition (purum axioma) we are in fact giving a narrow, specific definition of a pure proposition. But what we really intend is a broader, more general meaning that also includes quantified propositions:

Unde porro apparet: purum axioma hic dici per Synecdochen generis pro specie. Neque enim purum dicitur hic ad excludendum quodvis extraneum, sed illud solum, quod modus est. Hoc enim axioma utique purum est: Omne animal est homo. (...) Ergo pura propositio solum dicitur ad excludendos modos, qui postea enumerantur. Aristoteles eam vocat de inesse: quia solum significat, praedicatum subiecto inesse, vel non inesse. Non enim consignificat modum, quomodo insit. Unde alii etiam frequenter vocant has propositiones absolutae. ${ }^{89}$

Unlike the pure proposition in the narrow sense, then, the pure proposition in the broad sense, otherwise called absolute or de inesse, can include quantifiers.

Scheibler, like most of his contemporaries, gives no explicit reason for the exclusion of quantifiers from the range of modal terms. A short remark on this point is found in Felwinger, who criticizes in this regard the abovementioned definition of modus as adiacens rei determinatio given by Peter of Spain:

Nos dicimus, si haec modi descriptio deberet recipi, etiam modalem propositionem constituerent signa Omnis \& Nullus, quae tamen signa nec ab ipso Hispano inter modos referuntur..$^{90}$

Scheibler does not exclude adjectives and adverbs through a further extension of the concept of pure proposition, but through the common distinction between the different meanings of 'mode', which are progressively "skimmed off" until one finally arrives at the four traditional modal terms. Thus Scheibler distinguishes the material modes from the formal modes, placing in the first category that which "afficit materiam propositionis, hoc est, modificat subiectum aut praedicatum", and in the second that which "afficit ipsam dispositionem \& coniunctionem extremorum". As we have seen, this is a thoroughly traditional doctrine that attributes a modal function, but only in the material sense, to adjectives and adverbs, and distinguishes them from actual "formal" modes that concern the propositional dispositio.

It should be said, however, that, though it was widely employed, Scheibler's approach is not the only one present in post-medieval logic. For example, Bannes defends a threefold division between modi rei (which correspond to Scheibler's material modes), modi intellectus (which correspond to syncategorematic terms and particularly to quantifiers), and modal terms in the strict sense (which correspond to Scheibler's formal

\footnotetext{
${ }^{89}$ Scheibler 1665, I, 451.

${ }^{90}$ Felwinger 1664, 31.
} 
modes). The problem is once again that of the relation between some kinds of syncategorematic terms (first and foremost quantifiers, but also exclusive, exceptive, and reduplicative terms) and the sphere of modality.

It may be appropriate here to mention the treatment of another German author who was writing a few years after Scheibler, Johannes Weiss, whose discussion is striking for the extreme detail in which he goes into the different meanings of 'modus'. Weiss distinguishes three types of mode: 1) that modifying the parts of the proposition (subject and predicate); 2) that modifying the proposition as a whole through determinations external to the proposition itself; 3 ) that modifying the proposition as a whole through the determination of the nature of the propositional link obtained by means of the compositio terminorum. For Weiss only the last type corresponds to modality in the strict sense of the word.

Weiss develops his threefold distinction further. If we take the first type of mode that Weiss distinguished, i.e. where the mode determines the parts of the proposition, we can speak of six different sub-types of modality: 1a) cases in which an adjective is a way of determining the noun to which it refers; 1b) determinations made through nouns in apposition to the subject or the predicate (e.g. David filius Isai fuit pius or Maria est Mater Christi); 1c) forms of descriptive specification of subject or predicate, even if done through compound expressions (the example given is Christus aeternus aeterni Dei Patris filius est homo); 1d) the use of adversatives with the aim of specifying the subject or predicate through a limitation (e.g. Deus non est Deus mortuorum sed viventium); 1e) all adverbs; 1f) exclusive, restrictive, and reduplicative terms.

If meant to be exhaustive, Weiss' list might indeed give rise to objections. For instance, points 1b), 1c), and 1d) seem to give examples of the same basic mechanism: the descriptive specification of the subject or predicate through more or less complex constructions; even the restrictive or reduplicative terms praeter or qua, seem to be relevant in this context precisely insofar as they permit the construction of descriptive specifications of the subject or the predicate. The inclusion of exclusive terms (the example given in the text is Sola fides justificat) seems to create the problem of the possible modal meaning - with 'modus' understood in Weiss' broad sense - of quantifiers. As we have seen, Bannes considers quantifiers to be modi intellectus, while Weiss does not mention them at all in this context. As regards the exclusive, restrictive, and reduplicative terms, we find that Scheibler includes these among 'modes' taken in the improper sense, claiming "secundario modalis est, quae constat particula exclusiva, restrictiva aut limitativa". ${ }^{1}$ Felwinger includes the exclusivae, reduplicativae, limitativae, and exceptivae particles among the modal terms

\footnotetext{
${ }^{91}$ Scheibler 1665, I, 451.
} 
if the latter are considered generalissime, ${ }^{92}$ whereas both Dannhawer and Johannes Rapp consider the exclusivae, exceptivae, limitativae, and comparativae propositions secundario modals. ${ }^{93}$

In the second of Weiss' main types of mode, in which the modal term appears as an external determination of the proposition as a whole, Weiss claims that two different kinds of modality are possible: 2a) that which occurs "per ordinem ad hominem sive nostrum intellectum, qua ratione illae particulae creditum est, auditum est, scitum est dicuntur modi"; 2b) the modes "per habitudinem (...) ad objectum sive rem enunciatam" (in this case Weiss is referring to verum and falsum, which I shall discuss shortly in connection with modality).

For Weiss, a real modal determination can only be achieved through the four traditional modal terms. Thus, the modal term (as Weiss phrases it in a way which should by now be familiar to the reader),

totam terminorum compositionem in sese determinat, adeoque adjicit rationem \& modum, secundum quem praedicatum inexistit subjecto, \& ita specialem extremorum ad se invicem habitudinem exprimit. ${ }^{94}$

According to Weiss, then, the modal terms in the narrow sense - those that Scheibler calls formal modes - are limited to those that modify the propositional compositio, or habitudo, or dispositio. Scheibler uses this very same view as his starting point for disproving the increase in the number of modalities suggested by Peter Ramus. For Ramus - who includes all adverbial determinations in the field of modality - there is no reason to limit the number of modes to the six listed by Aristotle in the De interpretatione (the four traditional ones, plus verum and falsum). On the contrary, the modes capable of meaning "quomodo categorema in subiecto insit" are endless. ${ }^{95}$ This position, which did not lack for supporters in humanist circles ${ }^{96}$ represents an outright attack on the traditional foundations of the doctrine of modality, and was to be perceived as such by subsequent thinkers. To insist, as Weiss and Scheibler do, on the existence of a sharp distinction between material modes and formal modes also served as a basis on which to reject a conception of modality that we might perhaps label "rhetorical", according to which the principal function of modalities is to perform a semantic (rather than strictly logical) modification of the terms (rather than of the propositional compositio), and their number is indeterminate. Scheibler further criticizes the rhetorical conception of modality through the observation that the necessary and sufficient condition

\footnotetext{
${ }^{92}$ Felwinger 1664, 38.

${ }^{93}$ Rapp 1668, 39. Cf. Dannhawerus 1629, 340.

${ }^{94}$ Weiss $1653,6$.

${ }^{95}$ Ramus 1556, 193.

${ }^{96}$ Cf. Valla 1982, 238. Cf. Mack 1993, 90.
} 
for a proposition to be modal is not simply that it includes a modal term, but that this term "afficiat dispositionem propositionis". ${ }^{97}$ On Scheibler's view, propositions like Quod necessario urit, est ignis, in which the modalizer only affects one term and not the whole proposition, are to be considered non-modal. A similar idea is defended by Caselius, who explicitly attacks those who claim that the simple presence of a modal term is sufficient to classify a proposition as modal:

Alii sic definiunt: Modalis enunciatio est, in qua habetur vel Necesse vel Contingens vel Possibile vel Impossibile. Sed haec definitio est imperfecta, cum multae \& pene infinitae enunciationes dentur, in quibus istae particulae quidem inveniuntur, non tamen enunciationes modales, sed saltem absolutas efficiunt. ${ }^{98}$

After dealing with the problem of the definition of mode, Scheibler goes on to consider the question of the number of modal terms, once again rejecting Ramus' contention that there are an indefinite number of modes, and dealing with another classic problem: whether to include truth and falsity among the modes.

This is an Aristotelian problem, already much in evidence in the medieval logical debate. ${ }^{99}$ For Scheibler,

verum \& falsum non constituunt propositiones modales rigide loquendo. Ita patet. Nam verum \& falsum non important limitationem compositionis in se, sed exprimunt habitudinem totius enunciationis ad rem enunciandam. At modus, rigide loquendo, est determinatio compositionis dicti, in quantum compositio exprimit specialem habitudinem terminorum ad invicem. ${ }^{100}$

In this passage, the claim that a limitatio compositionis occurs in genuine modal propositions is interesting. The modification of the propositional compositio by the mode in this way seems to be a restriction. And in fact use of the term restrictio appears - linked to the definition of modus as adiacens rei determinatio inherited from Peter of Spain - in other authors, ${ }^{101}$ and is particularly explicit in Mendoza, who links this restrictio to the triplex materia propositionis:

Modus late sumptus est limitatio seu restrictio alicuius orationis, aut vocis, quae fit per terminos adiectivos (...) vel substantivos in obliquo (...) vel per adverbia, disiunctiones et caetera, de quibus non agimus in praesenti. Agimus autem de modo adstringente propositionem in una materia determinata. Diximus materiam esse triplicem, necessariam,

${ }^{97}$ Scheibler 1665, I, 452.

${ }^{98}$ Caselius 1633 , sect. I par. 2.

${ }^{99}$ Cf. Roncaglia 1996, 74, 83-87.

${ }^{100}$ Scheibler 1665, I, 453.

${ }^{101}$ Cf. e.g. Javellus 1629, 59v: "Modus est adiacens rei determinatio, i.e. modus est limitatio, sive restrictio." 
remotam, contingentem, cui triplex respondet modus, necessarius, impossibilis, contingens, quibus additur \& quartus, scilicet possibilis, qui tamen parum differt a contingenti. ${ }^{102}$

Restrictio as it is used here is clearly linked to the doctrine of restrictio applied to terms, a doctrine which seems to be extended to include the case of propositions and of their position within the classification given by the triplex materia.

Recent studies of medieval logic permit us to discern the existence, as early as the thirteenth century, of two alternative theories of the suppositio: one based on the idea that the basic suppositio of a term exclusively pertains to the present, and only through ampliatio can it be extended to other tenses; the other based on the idea that initially a term supposites for all tenses, and only through restrictio can it be specified to a particular tense. ${ }^{103}$ It is interesting to note that nearly four centuries later, ampliatio and restrictio seem once again to constitute the two poles of theories of modality that appear to be at least potentially different. Thus, while Scheibler and the other authors considered thus far maintain that the principal characteristic of a modal term is that it sets a limitatio or restrictio on the propositional link, there are also those like Dannhawer, who seem to see the mode rather as the instrument of an ampliatio. For Dannhawer, in fact, in order for a proposition to be called modal it is necessary

ut per modum amplietur enunciatum. (Ubi ampliare est efficere, ut propositio addito modo plus significet, quam sine eo). Hinc verum, falsum, opinabile non sunt modi, nam cum dico: Hominem esse animal est verum, non plus dico, quam homo est animal. ${ }^{104}$

As can be seen from this passage, the motivation for Dannhawer's use of ampliatio seems to be the same as that for Scheibler's use of limitatio: the need to eliminate verum and falsum from the number of modes. In these cases, both for Scheibler and for Dannhawer the compositio is determined, but whereas for the former it is not limited, for the latter it is not ampliated. ${ }^{105}$

Thus in this case too - though on the plane of propositions rather than terms - it seems that a distinction can be drawn between two types of theories: those (such as that presented in the Dannhawer passage quoted above) in which the idea that modality brings about an ampliatio compositionis is central, and those (like Mendoza's or Scheibler's) in which it is claimed that modality brings about a restrictio, singling out the specific materia propositionis of the corresponding non-modal proposition.

\footnotetext{
${ }^{102}$ Mendoza 1618, 136-37.

${ }^{103}$ Cf. e.g. Maierù 1972, 157 ff.; de Rijk 1982, 171-72.

${ }^{104}$ Dannhawerus 1653, 52.

${ }^{105}$ Cf. e.g. (Cornelius) Martini 1623, 230-31; Horst 1608, 213-14.
} 
The use of ampliatio also crops up, in a rather obscure way, in a passage from Calixt, in which the definition of modus as determinatio of the compositio as such is again proposed, but in addition there is found a rejection of the "modes" relative to subject and predicate or referring to the compositio considered with respect ad rationem nostram:

Modus est determinatio compositionis dicti in quantum compositio, specialem habitudinem terminorum ad invicem exprimens. Modum enim proprie accipimus, non pro quacumque determinatione aut modificatione solius sive subiecti sive praedicati, sive etiam compositionis, quae non spectatur quatenus compositio, sed quatenus ordinem habet ad rationem nostram sine ampliatione aut contractione. ${ }^{106}$

One may ask oneself here if the "sed quatenus ..." corresponds to the "non spectatur quatenus ..." immediately preceding it, or to the "non pro quacumque determinatione" further up. The first interpretation certainly seems the more convincing: as we have seen in Weiss, it is habitual to refuse to consider modifications such as scitum, creditum, etc. to be authentic modes. Such epistemic attitudes, it is claimed, affect the compositio propositionis not in itself, but with respect ad rationem nostram. This is a doctrine that is already to be found in some medieval authors (for example Roger Bacon), ${ }^{107}$ and seems to have gained adherents during the later period. Thus Kornelius Martini defines the mode as determinatio compositionis dicti in quantum compositio, and notes that this specification is used in order to exclude the modes that determine the compositio

non qua compositio, sed in quantum, ut inquiunt Scholastici, enunciationes habent ordinem ad rationem nostram. Ita creditum, imaginatum, iustum, pium \&c a modis excluduntur. ${ }^{108}$

To return to the question of the exclusion of truth and falsity from the list of modes, we can note that positions very similar to that of Scheibler are to be found in Caselius (according to whom Aristotle "verum \& falsum late \& per similitudinem modos vocat. Veri autem modi non sunt, cum non importent qualitatem dispositionis in se, sed exprimant habitudinem totius enunciationis ad rem enunciandam" ${ }^{109}$ ), in Zapfius, ${ }^{110}$ and (as we have seen) in Johannes Weiss. ${ }^{111}$ The basic idea seems to be that in this kind of "apparently" modal proposition, the determinatio compositionis does not occur with respect to the proposition itself, but with respect to something extrinsic to it: in the case of the epistemic modalities considered above this

\footnotetext{
${ }^{106}$ Calixtus (praes.) 1610, disp. V, par. 35-36.

${ }^{107}$ Cf. Roncaglia 1996, 85-86.

${ }^{108}$ (Cornelius) Martini 1623, 232. Cf. also Horst 1608, 213-14.

${ }^{109}$ Caselius 1633, sect. 1 par. 12.

${ }^{110}$ Zapfius 1658, 190.

${ }^{111}$ Weiss 1653, 5; for Weiss' views cf. above in the paragraphs before n. 94.
} 
extrinsic element is constituted by our intellect, in the case of truth and falsity, it is constituted by the external world of the res.

For the sake of completeness, what is probably the most common position on this matter should be mentioned: ${ }^{12}$ the view that verum and falsum, though affecting the propositional compositio, act as it were "without effect", without adding anything new to the non-modalized proposition. This position is essentially based on the redundancy of verum and falsum and was often supported by reference to the similar view defended in the De modalibus. Since this text was traditionally ascribed to Thomas Aquinas, it comes as no surprise to find it in authors like Bannes:

Aliqui addunt vere vel false, seu verum vel falsum, sed hoc superfluum est, nam commune est omni enunciationi significare vere vel false. Et qui dicit Petrus currit, perinde est, ac si diceret Petrus vere currit. (...) Est igitur superflua consideratio illius modi vere vel false. ${ }^{113}$

The same idea is found in other works influenced by Thomistic tradition, such as the Cursus Complutense ${ }^{114}$ or the Commentaria by Antist. Antist considers verum and falsum (as well as per se and per accidens) to be authentic modes, which, however, do not need to be dealt with specifically, since all propositions containing verum or falsum are reducible to non-modal propositions (and all containing per se and per accidens are reducible to modal propositions containing necessary or contingent). ${ }^{115}$ In general, the Iberian tradition can be seen to be quite "soft" in excluding truth and falsity from the number of modalities, and an author of the stature of Domingo de Soto appears to fully accept them. ${ }^{116}$

The refusal to include truth and falsity among the modal terms, when based on the idea of their redundancy, is nevertheless generally expressed in

\footnotetext{
${ }^{112}$ Naturally there exist other possible strategies. In Germany, for example, I have found no follower of the unlikely view defended by Tartaretus, according to which verum and falsum, and the epistemic modalities, do not require specific discussion because they are used less frequently and are not suitable for establishing rules of equipollence: "Licet sint plures modi facientes propositionem modalem, quam isti quatuor, tamen solum enumerantur isti quatuor quia sunt magis usitati. Etiam faciunt propositiones modales aequipollere per adventum negationis, non autem alii modi, cuiusmodi sunt, creditum, opinatum, verum \& falsum" (Tartaretus 1581, f. 27r). Tartaretus observes later (f. 27v) - without, however, arguing for this position - that verum and falsum can only constitute a compound modal proposition and not a divided one; thus, given that in his opinion only divided propositions are authentic modal propositions, this is a further strategy for excluding truth and falsity from the number of modes.

${ }^{113}$ Bannes 1618, 401.

${ }^{114}$ Cf. Collegium Complutense, 27.

${ }^{115} \mathrm{Cf}$. Antist 1617, $332 \mathrm{ff}$. The inclusion of per se and per accidens in the number of modes is also discussed among others in: Javellus 1629, 60v; Horneius 1633, 398; and Felwinger 1664, 41-43; all give similar solutions.

${ }^{116}$ Cf. D’Ors 1981, 680 (I am grateful to Angel D'Ors for having put at my disposal a copy of the sections on modal logic in this work, his doctoral dissertation).
} 
stronger terms than we see in Antist: verum and falsum, precisely because they do not add anything to the absolute proposition, do not effectively "modify" it or "determine" it. In German circles this position is clearly expressed by Horneius:

Observetur 2. nonnulla esse quae speciem modorum habeant, sed modi revera non sint, ut si dicas: omnem hominem esse animal verum est, homines ex saxis natos esse falsum est: non enim in iis determinatur quomodo praedicatum subjecto vel insit, vel non insit, sed simpliciter tantum inesse vel non inesse asseritur, ut in absoluta. ${ }^{117}$

The positions of Stahl ("hi modi non dicunt aliquid praeter simplicem compositionem subjecti \& praedicati. Per se enim verum est, hominem esse animal, etsi modus non addatur" 118 ) and of Ebel ("verum, falsum [...] non determinant, qua ratione praedicatum dicti subjecto conveniat, sed simpliciter tantum convenire vel non convenire dicunt" ${ }^{\text {"19 }}$ ) are similar. Sometimes, as in Dannhawer, ${ }^{120}$ in Kornelius Martini, ${ }^{121}$ or in Horneius' Disputationes logicae, ${ }^{122}$ this position is supported by the claim mentioned above, according to which in the case of verum and falsum the ampliatio compositionis is missing.

Keckermann supports an unusual view in which the propositions containing verum and falsum seem to be reduced not to absolute propositions, but to necessary and impossible propositions respectively. The justification for this reduction, however, seems problematic, given that Keckermann bases himself on the fact that "quod necessarium est, id verum est; quod impossibile, id falsum est", ${ }^{123}$ an observation obviously incapable of establishing the reduction of the true to the necessary and the false to the impossible. Keckermann also adopts a form of reduction with regard to the epistemic terms probabile and opinatum, which are reduced to contingens. ${ }^{124}$

The two strategies distinguished above for refusing to give verum and falsum a genuine modal status - that based on the reference to the plane of

\footnotetext{
${ }^{117}$ Horneius 1654, 79. Horneius treats the epistemic modalities in a fashion parallel to his treatment of verum and falsum, without resorting to the idea that through them the determinatio occurs in ratione ad intellectum - a problematic choice, since it is not clear how propositions in which epistemic modalities appear may be reducible to the corresponding propositions devoid of these modalities. In the Institutiones logicae Horneius adopts a somewhat different strategy (with reference to Albert the Great's commentary on De interpretatione), claiming that modes do not simply regard the being or non-being of things (like truth and falsity) but their relation with the causes of their being or non-being: cf. Horneius 1633, 397.

${ }^{118}$ Stahl 1656, 151

${ }^{119}$ Ebel 1681, 105.

${ }^{120}$ Dannhawerus $1653,52$.

${ }^{121}$ (Cornelius) Martini 1623, 230.

${ }^{122}$ Horneius 1628, 82.

${ }^{123}$ Keckermann 1614, col. 704.

${ }^{124}$ Ibid.
} 
the res and that based on their redundancy - seem to be simultaneously present in Felwinger (it is to be noted that with respect to the first strategy Scheibler's position has been adopted almost verbatim):

Verum \& falsum non veras efficiunt modales, quia non important limitationem compositionis subjecti \& praedicati inter se, sed exprimunt habitudinem totius enunciationis ad rem enunciatam. Nam oratio vera dicitur aut falsa ideo simpliciter, quod res sit aut non sit (...). Non itaque aliter significat haec enunciatio, Hominem esse animal verum est, ac haec, Homo est animal. ${ }^{125}$

After his discussion of the number of modalizers, Scheibler goes on to consider another classic issue in modal doctrines: the distinction between modality in the compound sense and in the divided sense. He presents this distinction by following the general lines of what I have elsewhere called the "syntactic approach": ${ }^{126}$ what determines whether a modal proposition is to be classified as being compound or divided is the position of the mode. If the mode is placed between the subject and the predicate, the modal proposition is divided; if, on the other hand, it is placed before or after, it is compound:

Vulgo Scholastici \& Logici hodierni dividunt ad hunc modum propositionem modalem, idque juxta diversitatem situs, quem habet particula modalis. Igitur modalis propositio divisa dicitur, in qua particula modalis ponitur intra praedicatum \& subiectum (...) Modalis autem propositio composita est, in qua totum dictum continue cohaeret, particula autem modalis praeponitur vel adponitur. ${ }^{127}$

A criterion of this type had been given in order to distinguish between de re and de dicto modal propositions already in De modalibus, and we find it again - alone or combined with other criteria - in many authors, including Titelmann, Dannhawer, Rapp, Kesler, and Stahl. ${ }^{128}$

This idea - that the position of the modal term within the modal proposition could constitute an (exclusive or non-exclusive, primary or derived) criterion for the classification of the modal proposition itself as compound or divided - was not without opponents. The common basis for criticism was generally the quite reasonable intuition that the order of the words constitutes an extrinsic and "superficial" feature of the proposition, incapable of establishing a deep logical difference such as the one proposed for analysis. This is a position to be found in Spanish authors: in fact Toletus noted that

\footnotetext{
${ }^{125}$ Felwinger 1664, 37-38

${ }^{126}$ Roncaglia 1996, $214 \mathrm{ff}$

${ }^{127}$ Scheibler 1665, I, 453.

${ }^{128}$ For more detailed references, cf. Roncaglia 1996, 215-17.
} 
At quamvis ista distinctio sensus compositi \& divisi sit verissima, \& tales enunciationes hosce sensus admittere recipiendum sit, non tamen refert (quantum existimo) quod modus in medio, vel extra ponatur, sed utcunque collocetur, utrunque sensum admittit. ${ }^{129}$

In Germany, the same position is taken up again by Horneius, who explicitly criticizes the passage from De modalibus in which propositions with the mode placed at the beginning are denied the status of modals, defining as de dicto those modal propositions in which the mode is predicated, and de re those modal propositions in which it is interposed: ${ }^{130}$

Thomas opusc. de enunciat. c. 11 differentias multas hic facit cum modus nomen est. Si enim praeponatur toti enunciationi, negat eam esse modalem sicut \& cum in medio collocatur: sin in fine, dicit vere modalem esse, eamque vocat modalem de dicto, ut illam ubi in medio modus est, modalem de re. Idem cum eo docent Iavellus tract. $3^{131}$ \& Tartaretus in Hispan. ${ }^{132}$ qui quam ille vocat modalem de dicto, appellant modalem de sensu composito, reliquas de sensu diviso. Sed (...) quod autores isti dicunt modum esse praedicatum in modali, atque ideo in fine collocandum, id parum firmum est. (...) Nihil igitur interest sive dicas: Necesse est hominem esse animal, sive: Hominem esse animal necesse est, sive denique Hominem necesse est animal esse. ${ }^{133}$

Johannes Weiss refers specifically to this passage from Horneius, as well as to Mendoza ${ }^{134}$ and to various German authors (Jacobus Martini - who, however, also grounds the difference between compound and divided modal propositions, at least in one passage, on the internal order of the proposition ${ }^{135}$ - Kesler, Arniseus) when he states that

hic (...) verum esse statuamus, eandem semper enunciationis manere formam, eundemque illius sensum, modus sive primo sive medio sive ultimo ponatur loco. ${ }^{136}$

${ }^{129}$ Toletus $1615-1616,41$.

${ }^{130}$ Thoma de Aquino 1976, 422.

${ }^{131}$ Javellus gives the criterion based on the order of terms as the first difference between compound and divided modal propositions, admitting however, in contrast to the $D e$ modalibus, that exceptionally in compound modal propositions the modal term could also precede the dictum: "Primo, in modali de sensu composito (...) modus aut preponitur aut postponitur toti dicto (...). In modali autem de sensu diviso modus nec preponitur nec postponitur dicto, sed mediat inter partes dicti" (Javellus 1629, 63r; cf. 61r for the exceptional admission of cases in which the modal term precedes the dictum). It is to be noted that Javellus also refers to the criterion constituted by the continuity of the utterance by the speaker: "Secundo differunt, quia modalis de sensu composito debet tota sine discontinuitate proferri, ut scilicet non fiat pausa inter partes dicti, nec inter dictum \& modum, sed continuetur prolatio (...). Ea autem, quae est de sensu diviso, proferri debet cum discontinuatione, ut scilicet proferatur subiectum dicti, \& in eo fiat punctum, deinde proferatur modus cum copula, \& reliquo dicti."

${ }^{132}$ The reference is to Tartaretus 1581, f. $27 \mathrm{v}$.

${ }^{133}$ Horneius 1633, 399-400.

${ }^{134}$ Mendoza 1618, 137: "Modus solet interponi (...) vel solet praeponi (...) vel solet postponi (...), semper tamen eundem reddit sensum."

${ }^{135}$ Cf. (Jacobus) Martini 1612, 71.

${ }^{136}$ Weiss 1653,14 
Scheibler, however, followed in this by Stahl and Kesler, does not consider the order of the words to be the sole criterion for determining whether a modal proposition is to be interpreted as being compound or divided, but adds the further criterion of the nominal or adverbial expression of the mode:

Coincidit cum hac divisione, quod aliqui ajunt, particulam modalem aliquando poni adverbialiter, aliquando nominaliter: illud, ut in propositione modali divisa; hoc, in composita. ${ }^{137}$

From where does Scheibler derive this approach? The distinction between adverbial and nominal expression of the mode, on the one hand, and that between the compound and the divided senses, on the other, are tied together in various ways especially in Spanish authors, and particularly in Fonseca, Toletus, and Bannes. ${ }^{138}$ To get an impression of this, let us see how Bannes appeals both to the nominal and adverbial expression of the mode, and to the order of the terms, rejecting the idea that the first criterion is sufficient, but claiming its usefulness in some cases in combination with the second:

Observet tamen Dialecticus non esse certam regulam sensus compositi, quando modus accipitur nominaliter (...). Rursus nec est certa regula modalis divisae, quod modus accipiatur adverbialiter. (...) At vero quando modus adverbialiter sumptus collocatur initio enunciationis, semper est modalis composita, ut haec: Possibiliter album est nigrum. Quando vero modus est nomen, \& ponitur pro altero extremo enunciationis respectu alterius extremi, quod est dictum sive enunciatum infinitivi modi, semper est modalis composita, verbi gratia Album esse nigrum est possibile. ${ }^{139}$

Bannes therefore believes that, in combination, the nominal or adverbial expression of the mode and the order of the terms are sufficient to identify only compound modal propositions. ${ }^{140}$ The position that he defends is that the mode expressed adverbially and placed at the beginning of the whole proposition characterizes a compound modal proposition. This clearly implies a full rejection of the view that Scheibler seems to defend, according to which adverbial modes are necessarily associated with divided modal propositions. This rejection is made even clearer by the subsequent recommendation that, when evaluating their truth value, one is to transform all compound modal propositions - and particularly those expressed nominally - into propositions in which the mode is expressed adverbially

\footnotetext{
${ }^{137}$ Scheibler 1665, I, 253-54.

${ }^{138}$ Cf. Roncaglia 1996, 222-27.

${ }^{139}$ Bannes 1618, 423-25.

${ }^{140}$ The proposition "album possibiliter est nigrum" is, according to Bannes, a divided one: cf. Roncaglia 1996, 231-33.
} 
and precedes the dictum, ${ }^{141}$ a structure which is thus given the distinction of being the "canonical form" of compound modal propositions.

In fact, the position according to which both compound modal propositions and divided ones admit both the nominal and adverbial expression of the mode is much more widespread than the one defended by Scheibler. One of the few authors who adopted Scheibler's view is Caspar Ebel, who notes that both in the case of compound and in that of divided modal propositions the mode can also be expressed verbally, but he too reserves the nominal expression for compound modal propositions and the adverbial expression for divided modal propositions. ${ }^{142}$

Moreover, Scheibler adds a further traditional criterion to those represented by the order of the words and by the nominal or adverbial expression of the mode: the idea that in the compound modal proposition the mode is always predicated, "nisi per trajectionem et dispositionem innaturalem". ${ }^{143}$ In this context, Scheibler adds the interesting observation that the role of the modal term within the proposition changes if you move from the isolated consideration of an individual proposition to the consideration of the relation between several propositions in a syllogism. Scheibler claims that in this case the mode is neither attributed to the subject nor to the predicate, but it is "ex parte copulae". ${ }^{144}$ The reason for this is clear: to maintain the possibility of applying the traditional rules of syllogistics even in the case of modal propositions, by avoiding the risk of having to add the modal terms (which might appear three times), to the three traditional terms considered in the syllogism. The theoretical basis for this "change of perspective" in moving from the consideration of an isolated proposition to that of a syllogism is however not nearly as clear, and Scheibler does not dwell on it at all. In this way, however, he approaches a problem - that of the relation between the modal term and the copula which embroiled German logicians in endless disputes, greatly influenced by the theological debate on the role of the copula in the eucharistic proposition hoc est corpus meum. This is a debate I have dealt with elsewhere, ${ }^{145}$ and cannot take up again here.

Another endless discussion concerned the question of whether compound and divided modal propositions were both to be considered "genuine" modal propositions, distinct in kind from absolute propositions. The best way to introduce the discussion on this point is perhaps to quote the list of contrasting auctoritates given by Scheibler:

\footnotetext{
${ }^{141}$ Bannes 1618, 426.

${ }^{142}$ Ebel 1681, 106.

${ }^{143}$ Scheibler 1665, I, 454.

${ }^{144}$ Ibid.

${ }^{145}$ Roncaglia 1997.
} 
Aliqui utrumque genus propositionis modalis constituere veras modales ajunt, et solum distinctas esse, quia habeant alium atque alium sensum. Ita Titelmannus l. 3 Log. consid. cap. $21 \&$ alii. (...) Jam vero alii existimant divisionem hanc propositionis modalis esse divisionem aequivoci solum, \& alterutrum genus modalium propositionum nomine tenus solum contineri sub enunciationibus modalibus. Attamen hoc est differenter: igitur aliqui ajunt, modales compositas, quas vocavi, esse non proprie modales, sed solum secundum similitudinem, quia in illis modus reperiatur, non tamen modificet. Ita sentit Tartaretus $\operatorname{Tr} .1$ in Sum. Hisp. \& alii. His ergo illae solum propositiones proprie sunt modales, in quibus modus subjecto \& praedicato interponitur, hoc est, quae divisae antea dicebantur. Atque de his etiam solum ait Titelmannus lib. 3 cap. 22 Aristotelem egisse sub nomine modalium enunciationum. In oppositum Fonseca In Inst. Log. p. 121 enunciationes modales compositas solum ait vere modales, $\&$ de his Aristotelem solum egisse. ${ }^{146}$

Scheibler essentially distinguishes three schools: according to the first, both kinds of modal proposition are accepted as "genuine"; according to the second, only divided modal propositions can be considered to be really distinct from absolute propositions; according to the third, only compound modal propositions are accorded this privilege. A fourth possibility can be added to the list: that neither the divided nor the compound propositions really differ from absolute propositions. This, as we shall see, also had its supporters, including Scheibler himself. There is the further issue of the very possibility of distinguishing between compound and divided modal propositions, a possibility denied by several authors, a point to which we shall return. Thus, all things considered, all the possible theses had supporters - a situation which, as it is easy to imagine, did not particularly enhance the clarity of the doctrine.

Scheibler cites Titelmann as one of the supporters of the first and more tolerant line; he believes "non omnino irridendi" the supporters of the validity of the distinction between compound and divided sense, and seems to consider the distinction itself as being well within the field of modal propositions. ${ }^{147}$ A similar conception can be found in Stahl, who, after noting how the "moderns" seek to reduce compound modal propositions to absolute ones, states that this strategy is effective only "in modo argumentandi recentiorum"; in contrast, "in ratione concludendi peripatetica" this reduction does not work. ${ }^{148}$ The view of those whom Stahl calls "recentiores" seems to take the modal term to be a full-fledged component of the proposition even in the syllogistic context. With modal propositions interpreted in this way, it is impossible to construct a syllogism in which the subject and predicate of the dictum appear as independent terms, without including more than the three usual terms. According to the

${ }^{146}$ Scheibler 1665, I, 454.

${ }^{147}$ Cf. Titelmannus $1545,124 \mathrm{r}-\mathrm{v}$. Titelmann seems however to give a certain preference to compound modal propositions, claiming that the divided ones "per omnia subiaceant legibus supra aliis simplicibus enunciationibus assignatis". In this way he approaches Fonseca's position.

${ }^{148}$ Stahl 1656, 149-50. 
"ratio concludendi peripatetica", however, the modal term is not considered an actual term within the syllogism, but is placed as it were "outside" the individual propositions used: thus, the modal term is not "counted" and the rule that there are only three terms is upheld. In Stahl's opinion, this justifies differentiating between compound modal propositions and absolute propositions, and hence viewing both compound and divided modal propositions as "genuine" classes of modal propositions.

At first, Scheibler too might appear to defend the first of the positions described above, since he states "nos utrumque genus modalium acceptamus". But in actual fact, as has already been hinted at, he should perhaps rather be seen as an adherent of the fourth position, given that he seems to deny that either compound or divided modal propositions differ in kind from absolute propositions:

Neque enim enunciatio modalis dicenda est ex eo, quia ratione istorum attributorum [affirmation, negation, opposition, etc.] differat ab aliis enunciationibus, sed quia habet particulam modalem, hoc est, talem, quae modificet dispositionem dicti, quod utrobique est. $^{149}$

Nihusius arrives at this same conclusion - though it is expressed far more explicitly - after complex argumentation, and it significantly gives the title to the second chapter of his treatise: "Neque modales compositas, neque divisas, differre ab absolutis". ${ }^{150}$ In his opinion the demonstration is immediate in the case of compound modal propositions. ${ }^{151}$ In fact, they preserve the subject-copula-predicate structure, given that the dictum as a whole acts as subject and the modal term as predicate. The copula of the dictum is not modified, since the modal term does not "enter" the dictum itself. Moreover, for Nihusius many absolute propositions have the same formal structure as compound ones: Socratem esse animal est necessarium from this point of view does not differ from Socratem esse animal est verum, and similar structures are found in propositions such as: impios placere Deo, credibile non est; hominem esse solum, bonum non est; or Icarum volasse, fabula est.

The question is more complex in the case of divided modal propositions. If we admit that the copula in these propositions is in effect different from the copula that is present in absolute propositions, we would have, according to Nihusius, a strong ground for recognizing the existence of a difference in kind between the two categories. But in his opinion this situation does not obtain: in divided modal propositions it is in fact the predicate, rather than the copula, that is affected by the mode (a point we shall return to shortly); therefore, they too preserve the normal subject-copula-predicate structure

\footnotetext{
${ }^{149}$ Scheibler 1665, I, 454.

${ }^{150}$ Nihusius 1621, 19.

${ }^{151}$ Ibid., 20: "De compositis res est clara (...)".
} 
typical of absolute propositions. Furthermore, in this case too, examples may be given of propositions normally considered absolute that have a structure similar to divided modal propositions, such as Socrates omnino est homo, Deus certissime est vindex scelerum (note the recurrence of theological examples), Homerus facile est poetarum princeps. ${ }^{152}$

Nihusius insists that modal and absolute propositions are of the same kind in his brief Schediasma de modalibus enunciationibus added to the Hypodigma of 1648, in reply to criticism from Kinderlingus, the successor of Kornelius Martini and Horneius as teacher of logic at Helmstedt. ${ }^{153}$

Among the authors who only give one of the two types of propositions compound or divided - the status of being genuinely modal, the definite majority seem to hold Abelard's position, ${ }^{154}$ which was to favour the divided proposition. Scheibler, as we have seen, cites Tartaretus in this regard, but the majority of the "Renaissance nominalists" studied by Coombs appear to be of the same opinion. ${ }^{155}$ The same view was to be supported by Scharf, who observes that only in divided modal propositions is the copula actually modified, whereas the compound ones preserve the same general structure as absolute propositions. ${ }^{156}$ Similarly, Weiss informs us that modal propositions strictly taken are not the compound but the divided ones, since only in them is the "propositionis dispositio" modified. ${ }^{157}$ Caselius also agrees with Tartaretus that in the case of compound propositions "modus non arguit novam compositionem": a proposition of this type is therefore only modal "improprie dicta". ${ }^{158}$ Felwinger, who devotes considerable space to contesting the arguments of Nihusius touched on above, also believes that if you take compound propositions to be propositions in which the mode is the predicate and the dictum the subject, you cannot speak of them being genuine modal propositions. ${ }^{159}$

As for favouring compound modal propositions, Scheibler cites Fonseca as his auctoritas. The distinction between compound sense and divided sense, however, does not explicitly appear in this Portuguese author, in whom we find instead the dual distinction between the nominal and adverbial expression of the mode and between actus exercitus and actus signatus. But the distinction between the nominal and adverbial expression of modality is phrased by Fonseca in terms that are very close to those traditionally used for the distinction between the compound sense and the

\footnotetext{
${ }^{152}$ Nihusius 1621, 22.

${ }^{153}$ Nihusius 1648, 344

${ }^{154}$ Cf. Roncaglia 1996, 59.

${ }^{155}$ Coombs gives loci by Georgius Bruxellensis, Tartaretus, Caubraith, Enzinas, Cueto: cf. Coombs 1990b, 26 n. 62.

${ }^{156}$ Scharfius 1632, 595; Scharfius, 1652, 186.

${ }^{157}$ Weiss 1653, 20.

${ }^{158}$ Caselius 1633, par. 20.

${ }^{159}$ Felwinger 1664, 66-67.
} 
divided sense. ${ }^{160}$ Fonseca, however, does not consider propositions in which the mode is expressed nominally to be the only authentically modal ones, as Scheibler's reference to him seems to suggest, but he does consider them to be the most common and for this reason the only ones discussed by Aristotle. ${ }^{161}$ A certain priority given to compound modal propositions is also to be found in some authors of the Thomistic tradition, probably due to the influence of the above-mentioned passage (at n. 86) from De modalibus in which the view is endorsed that the mode should be placed as predicate of the whole dictum. We see this clearly in Antist, who observes that "claritatis gratia semper agemus de ipsis [modal propositions] in sensu composito, ne modus positus intra partes dicti rem obscuram obscuriorem efficiat." 162

As was mentioned, the outright rejection of the distinction between the compound and the divided sense is also widespread in this period, and it is often based on the claim that compound propositions are reducible to divided ones. Dannhawer defends this position by appealing to the same conception of the relationship between modal proposition and syllogism that we have seen Stahl refer to as the "modus argumentandi recentiorum":

Observo, propositionem modalem compositam esse ineptam ad Syllogismum, nam quia in hac modus est praedicatum, fieret, si ter modus repeteretur, unum terminum ter poni in Syllogismo: ut igitur fiat apta, reducenda est ad modalem divisam, ubi modus imitatur quantitatem dicti. ${ }^{163}$

Dannhawer argues for this reduction by appealing to the idea that there is a merely formal difference between compound and divided modal propositions - substantially their meaning is the same and one should judge them accordingly:

Hoc omnium primo constare oportet, modalium compositarum idem esse judicium cum modalibus divisis, neque quantum hoc attinet inter ipsas discrimen constitui debere, quod est contra Nihusium, qui operosus est in hoc discrimine adsignando. ${ }^{164}$

In order to justify this view, Dannhawer resorts to Fonseca's statement that in the compound modal proposition (Fonseca, remember, actually talks of the nominal expression of the mode: see above at nn. 160-61) the mode acts on the copula of the original dictum, so that the copula could be considered its actual subject. ${ }^{165}$ It is therefore not true that in the compound modal proposition the mode remains "external" to the dictum; on the contrary, both

\footnotetext{
${ }^{160}$ For a closer scrutiny of Fonseca's modal theories, cf. Roncaglia 1996, 221-25.

${ }^{161}$ Fonseca 1964, 158: "Sed nos priori formula omissa, quia minus usurpata est (saltem in modalibus ex possibili, et impossibili) solam posteriorem imitatione Aristotelis tractabimus."

${ }^{162}$ Antist 1617, 336.

${ }^{163}$ Dannhawerus $1653,53$.

${ }^{164}$ Dannhawerus 1629, 325.

${ }^{165}$ Fonseca 1964, 158.
} 
the compound and the divided modal proposition express the same modification of the link between the terms of the dictum. The reduction of compound to divided modal propositions is therefore justified ("idem est dicere Hominem esse animal necesse est, sive haec propositio quae asserit hominem esse animal, necessaria est, ac si diceres Homo necessario est animal $\left.^{\prime 166}\right)$, and is in fact required, as we have seen, in the case of modal syllogistics. Dannhawer gives us an example by reducing the syllogism Necesse est omne risibile esse hominem, Quoddam album est risibile, ergo Necesse est quoddam album esse hominem, to the one in which only divided modal propositions appear, Omne risibile necessario est homo, Quoddam album est risibile, ergo Quoddam album necessario est homo.

In order to lend credibility to this strategy, Dannhawer has to explain the difference in truth value that frequently appears to exist between compound and divided modal propositions. We find here a conception defended also by Felwinger: when there are differences in truth value, they do not derive from the presence of two different kinds of proposition, but from the different suppositio of the terms.

Non est mirum, si diversus sensus oriatur, quando suppositio terminorum mutatur, quemadmodum enim haec vera est, Non omnis pars hominis est corporea; haec falsa, Omnis pars hominis non est corporea; neque tamen ideo toto genere diversum judicium de is instituitur. Ita (...) in singulis positis exemplis [These are classic examples of propositions true in the divided sense and false in the composite sense] variatur suppositio, semper enim modalis ut composita supponitur vel simpliciter, vel copulative: ut divisa, distributive, illic sine descensu, hic cum descensu. ${ }^{167}$

If Felwinger seems to have lifted these statements virtually verbatim from Dannhawer, ${ }^{168}$ the two authors differ in the opinion they have of the relation between modal propositions and absolute propositions. Once the existence of a distinction in kind between compound and divided modal propositions has been denied, Dannhawer believes in fact that he can also deny the existence of a distinction of this type between absolute propositions and the entire range of modal propositions:

Praecognoscendum est modalem propositionem non differre specie ab absoluta, nec novis hic opus esse praeceptis, sed omnia se eodem habere modo, ut in syllogismis de inesse. ${ }^{169}$

This claim derives from the conception of the relation between mode, copula, and predicate that Dannhawer defends, according to which the mode does not act on the copula but on the predicate - indeed, it is part of the predicate itself: the copula in the case of a modal proposition is therefore

\footnotetext{
${ }^{166}$ Dannhawerus 1629, 326.

${ }^{167}$ Ibid., 328.

${ }^{168}$ Cf. Roncaglia 1996, 234-35.

${ }^{169}$ Dannhawerus 1629, 331.
} 
formally similar to one in an absolute proposition. The theory described here does not seem to agree entirely with the passage from Fonseca that Dannhawer referred to when denying the distinction between compound and divided modal propositions (see above at n. 165), since Fonseca's text employed the idea that, by acting on the copula, the mode "penetrates" the dictum even in the case of compound modal propositions. And Felwinger uses the same idea - that the mode modifies the modus connectendi of the copula - when he rejects the arguments of those who, like Dannhawer, deny the existence of a difference in kind between modal and absolute propositions:

Sola facultas connectendi una \& eadem non sufficit ad identitatem formae seu copulae, sed requiritur unus idemque connectendi modus, qui in absoluta alius est a copula modali. Verum quidem est, copulam in modali aeque ac in absoluta connectere praedicatum cum subiecto, sed non aequaliter. ${ }^{170}$

As we have seen, the interplay of the positions taken on the issue of whether to accept the difference between compound and divided modal propositions and that between modal and absolute propositions is extremely complex, and makes any simplification difficult.

After dealing with this problem, Scheibler goes on to discuss the quality and quantity of modal statements. As far as quality is concerned, Scheibler defends the position that the truth or falsity of modal propositions is similar to that of absolute propositions, and he adds an interesting observation concerning iterated modalities:

Convenit etiam modalibus veritas \& falsitas ita, ut quaecunque est vera, sit item necessaria. Et quaecunque est falsa, eadem sit impossibilis. Atque ita non datur modalis enunciatio, quae sit contingenter vera. ${ }^{171}$

This is a view with a long history, ${ }^{172}$ and Scheibler refers explicitly to the authority of Fonseca, who had written:

(...) De veritate et falsitate modalium, hoc dicendum est, modales esse quidem veras, aut falsas, (...) caeterum eas, quae verae sunt, numquam posse esse falsas, et quae sunt falsae, veras esse numquam posse: ac proinde omnes esse aut necessarias, aut impossibiles. ${ }^{173}$

As regards quantity, the position defended by Scheibler, which is again traditional (Scheibler cites in this context Titelmann, Keckermann, and Nihusius), is that divided modal propositions can be universal or particular like absolute propositions, whereas compound modal propositions are,

\footnotetext{
${ }^{170}$ Felwinger 1664, 22.

${ }^{171}$ Scheibler 1665, I, 455.

${ }^{172}$ For a closer look at the post-medieval discussions on iterated modalities, cf. Coombs 1990a.

${ }^{173}$ Fonseca 1964, 160.
} 
proprie loquendo, only particular. According to Scheibler, with only slight reservation we can also accept Fonseca's view, ${ }^{174}$ according to which necessary and impossible propositions connote universality, while possibile and contingent ones connote particularity. As in Fonseca, the basis for this view lies in the relation between modal sphere and temporal sphere: necessity and impossibility imply the truth or falsity in all times of the corresponding absolute propositions, contingency and possibility their truth or falsity at some time.

As has been mentioned (see above at n. 91), Scheibler also includes in the section devoted to modality (though in a separate Titulus, the third) an analysis of the exclusive, exceptive, restrictive, and reduplicative terms. This is a very interesting subject, but the connection with actual modal issues is at least in Scheibler - quite weak, and to deal with it in any depth would require going into the late medieval de exponibilibus tradition, which is too vast and complicated to take up here. We shall therefore conclude our analysis of Scheibler's text with the last article of Titulus II, devoted to answering the question "An doctrina modalium sit necessaria".

This was not an uncommon question at the time, because the sixteenth century reaction of humanist and Ramist logicians against what was perceived to be the excessive and often inconclusive formalism typical of the scholastic tradition tended to affect most of the traditional logical doctrines, including the discussion of modal issues.

Lorenzo Valla had already put forward a strong criticism of the function of modal doctrines: in chapter 18 of the second book of the Repastinatio he defends right from the title the radical view "non esse enuntiationes modales". ${ }^{175}$ Juan Luis Vives' view that the De interpretatione contains doctrines that are grammatical rather than authentically dialectic seems to have been very influential:

Succedit Categoriis liber Peri ermeneias, id est, de interpretatione, quod, ut nomen ipsum sonat, magna ex parte grammatici est potius quam dialectici officii. ${ }^{176}$

In particular,

pronuntiata illa quibus additur modus non habent dialecticam, sed grammaticam quaestionem,

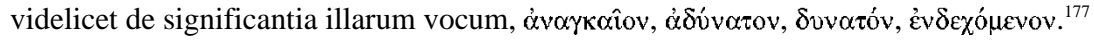

\footnotetext{
${ }^{174}$ Fonseca 1964, 161.

${ }^{175}$ Valla 1982, 237. The chapter is the nineteenth in Opera omnia (Valla 1962), tomus prior, 716.

${ }^{176}$ Vives, De causis corruptarum artium, in Opera omnia (Vives 1782), VI, 116; cf. Vives, De Aristotelis operibus censura, in Opera omnia (Vives 1782), III, 27; Risse 19641970, I, 37; Guerlac, introduction to Vives 1979, 38.

${ }^{177}$ Vives, De causis corruptarum artium in Opera omnia (Vives 1782), VI, 117.
} 
It was mentioned above that Ramus also criticizes the scholastic tradition with regard to modality, contesting the reduction of the number of modes to the usual four. Melanchthon, an obviously important author in Protestant Germany, seems ambivalent. On the one hand, at the beginning of the section of the Erotemata dialectices devoted to modality he notes that

Utilitas autem huius partis ingens est, quia hic discrimen illustratur inter necessaria et non necessaria. Hos rerum modos agnosci et discerni adeo refert, ut horribilis confusio errorum sequatur, cum non considerantur. ${ }^{178}$

On the other hand, as has already been mentioned (above, at and around $\mathrm{n}$. 61), in most of the Erotemata Melanchthon puts forward a metaphysical rather than a purely logical conception of modality, while, for example, the discussion of an apparently more "logical" topic such as the equipollence between modalized propositions is explicitly relegated to the grammatical field. ${ }^{179}$

The idea that the discussion of modal issues must be brief and concise is often put forward by those authors who want to deny the existence of an essential difference between modal and categorical propositions. Thus we find both views clearly supported in the Dialectica by Johannes Caesarius, accompanied by the opinion that modal doctrine "plus habet difficultatis, quam utilitatis". ${ }^{180}$ Similar reservations towards modal logic are perceptible in various authors influenced by the humanistic tradition; Johannes Eck notes in this regard that

artem modalium tradentes in ea diutius morantur, tot regulas applicantes, ut saepius auditores remittant hebetiores quam doctiores. ${ }^{181}$

For his part Johann Heinrich Alsted - defender of a "practical logic" aimed at identifying a few precepts applicable in practice - in his Compendium gymnasii logici devotes only these few significant observations to the propositio modalis:

Modales propositiones sunt, in quibus exprimuntur haec vocabula: necesse, contingens, possibile, impossibile. Hae sunt reducendae ad puras, ne sophistarum tricis involvamur. ${ }^{182}$

Though devoting quite a large space to the discussion of modal propositions, Bartholomaeus Keckermann is also clearly influenced by the humanist tradition, and in his Systema logicae he gives as the first of five

\footnotetext{
${ }^{178}$ Melanchthon 1846, col. 589.

${ }^{179}$ Cf. Roncaglia 1996, 153 and Roncaglia 1998.

${ }^{180}$ Caesarius 1539, 80.

${ }^{181}$ Eckius 1516, 20, cit. in Seifert 1978, 131 n. 42 (cf. ibid., 52).

${ }^{182}$ Alsted 1611, 82
} 
canones modalium propositionum: "modalium maior est apud Graecos usus, quam apud Latinos". ${ }^{183}$ Keckermann goes on to observe that

Haud scio magis ne doctrinam modalium Scholastici exercuerint, quam ea illos vexarit. Certe usque adeo sudatum hic fuit, ut dicterio locus sit datus: De modalibus non gustabit asinus. Sed hoc certum, magnas spinas a spinosis ingeniis huic doctrinae intextas esse, quibus discentium ingenia lacerentur, non solidentur. (...) In Graecorum enim disputationibus frequentissime usurpati sunt isti termini modales (...); apud Latinos vix audias inter disputandum modos istos, nec memini magnum unquam periculum in disputatione creatum fuisse illi, qui doctrinam modalium ignoravit. ${ }^{184}$

It is easy to understand why authors like Scheibler, involved in a discussion in which modal doctrine was an essential element, felt that a defense of its utility was necessary. In general these defenses were based on the philosophical and above all (although not in Scheibler's case) the theological usefulness of the doctrine. Many examples were offered in the attempt to show that modal problems are by no means far-removed from everyday use. Far from being a sterile and abstract exercise, the discussion of these topics is rich in applications, and ignorance of this subject leads to very serious errors, and opens the way to the worst heresies - a position shared by many authors, who nevertheless disagreed on the precise errors "unmasked" by a correct conception of modality, and on what this correct conception was. Often long lists of biblical passages in which modal terms appeared were quoted in defense of modal theories, ${ }^{185}$ accompanied by demonstrations of the need for a logical, and not purely linguistic, consideration of their use and meaning. The favourite examples, however, were the propositions on which interconfessional controversy was strongest: what meaning is to be attached, for example, to 'necessary' in saying that good works are necessary for salvation, or that it is necessary that the predestined be saved? ${ }^{186}$ More rarely, the consideration of theological propositions in which modal terms explicitly appear is accompanied by a consideration of non-modal propositions, which, however, since they express revealed truths, must necessarily be true. ${ }^{187}$

After mentioning Vives and Ramus as the major opponents of the usefulness of modal theories, Scheibler defends the need for them in a fourpoint response:

1. Ut intelligantur ea, quae magno cum apparatu ab aliis docentur de modalibus. Turpe certe est artifici logico, quae tam operose ab aliis perquiruntur, plane ignorare. 2. Sed tamen inprimis necessitas hujus doctrinae est evidens, porro inde, quod maxime intersit, ut Logicus sciat bene discernere contradictorias, cum in earum differentia fundetur omnis deductio in

\footnotetext{
${ }^{183}$ Keckermann 1614, col. 703.

${ }^{184}$ Keckermann 1614, coll. 703-704.

${ }^{185}$ Cf. e.g. Horneius 1654, 79; Scharfius 1632, 990.

${ }^{186}$ Cf. e.g. Horneius 1624, 58.

${ }^{187}$ Cf. e.g. Neldelius 1666, 390.
} 
absurdum. At facile errare potest Logicus in hac materia, nisi sciat, quomodo modalibus contradicatur. 3. Proinde necessarium etiam est, nosse quantitatem \& qualitatem modalium, cum contradictio fiat mutando quantitatem \& qualitatem propositionis praejacentis. 4. Facile falli potest in syllogismis modalibus qui non novit doctrinam modalium enunciationum (....). ${ }^{188}$

Two aspects of this passage deserve special mention: 1) The stress on the necessity of bene discernere contradictorias, a necessity which is used to ground both the second and the third points given in defense of the utility of modal theory. The logician needs of course to recognize and to avoid contradictions - a fact that hardly seems debatable - but the great stress put on this point is common to many Protestant logicians, and is probably influenced by Melanchthon, who often explicitly considers contradiction not only as a logical, but also as a theological deception. ${ }^{189}$ In Scheibler, however, there appears no trace of theological concern. 2) In fact, quite to the contrary: in a period in which most of the defenses of modal theory elaborate on its theological relevance, Scheibler's own is entirely internal to the field of logic. For Scheibler, the utility of modal logic is not the result of its use as a theological weapon, but simply of its being an important part of logic.

The discussion of the utilitas doctrinae closes the section devoted to modality in Scheibler's Opus Logicum. And the very fact that this section ends with such a proud and "technical" defense of modal logic should suggest that it would be unwise to hastily dismiss as uninteresting seventeenth century "scholastic" discussions on modal logic. This paper will have served its purpose if it has managed to offer some more reasons for such a critical reassessment.

\section{REFERENCES}

Alsted, Johannes Henricus 1611 Compendium I Systematis Logici, de septem instrumentorum logicorum architectura \& fabrica; II Gymnasii logici, de applicatione instrumentorum Logicorum dianoetica \& mnemonica, uno libro explicati. Herbornae Nassoviorum.

Alsted, Johannes Henricus 1623 Nucleus logicae, complectens praxin artis nobilissimae. Herbornae Nassoviorum.

Antist, Vincens Iustinianus 1617 Commentaria in universam logicam una cum lucidissimis quaestionibus. Coloniae Agrippinae.

Aquinas, Thomas: cf. Thoma de Aquino.

Bannes, Dominicus 1618 Institutiones minoris dialecticae, quas Summulas vocant. Coloniae.

Bartholinus, Caspar 1628 Enchiridion logicum. Argentorati.

${ }^{188}$ Scheibler 1665, I, 456.

${ }^{189}$ Melanchthon 1846, coll. 562: "Hic ordo, ne duae contradictoriae simul verae sint, aut simul falsae, est regula immota et aeterna mentis divinae (...) Et hunc ordinem tollere, est omnia facere incerta, et totam rerum universitatem confundere." Cf. also coll. 585-86, 590, 701; on this point, cf. Roncaglia 1992, 92-94. 
Boethius 1880 In librum Aristotelis Peri Hermeneias, editio secunda, ed. C. Meiser. Lipsiae: Teubner.

Caesarius, Iohannes 1539 Dialectica. Lugduni.

Calixtus, Georgius (praes.) 1610 Disputationes logicae. Helmaestadii.

Calixtus, Georgius 1652 Tractatus de arte nova, quam nuper commentus est Bartholdus Nihusius (...) juxta impressionem Helmstadiensem editio prima. Francofurti.

Caselius, Martinus (praes.) 1633 Disputatio logica de modalium et exponibilium enunciationum natura et affectionibus. Wittebergae.

Collegii Conimbricensis e Societate Jesu Commentarii in universam dialecticam Aristotelis. Rpt.: Nachdruck der Ausgabe Coloniae 1607, mit einem Vorwort von W. Risse, Hildesheim: Olms, 1976.

Collegium Complutense philosophicum, hoc est, artium cursus sive disputationes in Aristotelis dialecticam et Philosophiam naturalem. Francofurti ad Moenum 1629 (an anastatic rpt. of the edition Lugduni 1668 is available: Collegii Complutensis disputationes in Aristotelis dialecticam, mit einem Vorwort von W. Risse, Hildesheim: Olms, 1977).

Coombs, J.S. 1990a 'John Mair and Domingo de Soto on the Reduction of Iterated Modalities', in: I. Angelelli and A. d'Ors (eds.), Estudios de historia de la logica: Actas del 2. simposio de historia de la logica (Universidad de Navarra, Pamplona, 1987). Pamplona: Ediciones Eunate, 161-81.

Coombs, J.S. 1990b 'The Truth and Falsity of Modal Propositions in Renaissance Nominalism', PhD Diss., The University of Texas at Austin.

Dannhawerus, Johannes Conradus 1629 Idea boni disputatoris et malitiosi sophistae. Argentorati.

Dannhawerus, Johannes Conradus 1653 Decas diatribarum logicarum in sex syllogas distributa. Francofurti.

De Rijk, L.M.: cf. Rijk, L.M. de.

Dorbellus, Nicolaus [Nicolaus de Orbellis] 1516 Logica, una cum textu Petri Hyspani. Venetiis.

D’Ors, A. 1981 La logica de Domingo de Soto, Ph.D. Diss., Pamplona.

Ebel, Caspar 1681 Compendium logicae plenius. Giessae.

Eckius, Johannes 1516 In summulas Petri Hispani extemporanea et succinta, sed succosa explanatio. Augsburg.

Eschweiler, K. 1928 'Die Philosophie der spanischen Spätscholastik auf der deutschen Universitäten des 17. Jahrhunderts', in: Spanische Forschungen der Görresgesellschaft, Bd. I (Gesammelte Aufsätze zur Kulturgeschichte Spaniens - Erste Reihe). Münster: Aschendorff, 251-325.

Felden, Johannes a 1642 Tractatus de enunciationibus et syllogismis cum absolutis tum imprimis modalibus. Helmaestadii.

Felwinger, Johannes Paulus 1664 Palaestra rationis, hoc est Doctrina enunciationum et syllogismorum modalium. Altdorfi.

Fonseca, Pedro da 1964 Institutionum dialecticarum libri octo, ed. J. Ferreira Gomez. Coimbra: Universidade de Coimbra.

Freedman, J.S. 1985 Deutsche Schulphilosophie im Reformationszeitalter (1500-1650). Münster: Maks.

Freedman, J.S. 1988 European Academic Philosophy in the Late Sixteenth and Early Seventeenth Centuries. The Life, Significance, and Philosophy of Clemens Timpler (1563/4-1624), 2 vols. Hildesheim: Olms.

Hispanus, Petrus: cf. Petrus Hispanus.

Horneius, Conradus 1624 De processu disputandi liber. Francofurti.

Horneius, Conradus 1628 Disputationes logicae. Francofurti.

Horneius, Conradus 1633 Institutionum logicarum libri V. Francofurti.

Horneius, Conradus 1654 Compendium dialectices succinctum \& perbreve. Jenae. 
Horst, Gregorius 1608 Institutionum logicarum libri duo. Wittebergae.

Jacobi, K. 1980 Die Modalbegriffe in den logischen Schriften des Wilhelm von Shyreswood und in anderen Kompendien des 12. und 13. Jahrhunderts. Leiden - Köln: Brill.

Javellus, Chrysostomus 1629 Logicae compendium. Coloniae Agrippinae.

Keckermann, Bartholomaeus 1614 Systema logicae tribus libris adornatum, in: Operum omnium tomus primus, ed. Genevae, coll. 541-832.

Kesler, Andreas 1623 De consequentia tractatus logicus. Wittebergae.

Knuuttila, S. 1981 'Time and Modality in Scholasticism', in: S. Knuuttila (ed.), Reforging the Great Chain of Being. Dordrecht: Reidel, 163-257.

Knuuttila, S. 1982 'Modal Logic', in: Kretzmann, Kenny, and Pinborg 1982, 342-57.

Knuuttila, S. (ed.) 1988 Modern Modalities. Studies of the History of Modal Theories from Medieval Nominalism to Logical Positivism. Dordrecht: Reidel.

Knuuttila, S. 1993 Modalities in Medieval Philosophy. London: Routledge.

Knuuttila, S. and J. Hintikka (eds.) 1986 The Logic of Being. Historical Studies. Dordrecht: Reidel.

Kretzmann, N. 1981 “'Sensus compositus”, "sensus divisus” and Propositional Attitudes', Medioevo 7, 195-229.

Kretzmann, N., A. Kenny, and J. Pinborg (eds.) 1982 The Cambridge History of Later Medieval Philosophy. Cambridge: Cambridge University Press.

Leinsle, U.G. 1985 Das Ding und die Methode. Methodische Konstitution und Gegenstand der frühen protestantischen Metaphysik. Augsburg: Maro.

Lounela, J. 1978 Die Logik im XVII Jahrhundert in Finnland. Helsinki: Suomalainen Tiedeakatemia.

Mack, P. 1993 Renaissance Arguments. Valla and Agricola in the Tradition of Rhetoric and Dialectic. Leiden: Brill.

Maierù, A. 1972 Terminologia logica della tarda scolastica. Roma: Edizioni Ateneo.

Martini, Cornelius 1623 Commentariorum logicorum adversus Ramistas libri V. Helmaestadii.

Martini, Jacobus 1612 Logicae Peripateticae per dichotomias in gratiam Ramistarum resolutae libri duo. Wittebergae.

Melanchthon, Philippus 1846 Erotemata dialectices, in: C.G. Bretschneider (ed.), Corpus Reformatorum, vol. XIII. Halis Saxonum: Schwetschke.

Mendoza, Pedro Hurtado de 1618 Disputationum a Summulis ad Metaphysicam (...) volumen primum, Summulas \& Logicam continens. Tolosae.

Neldelius, Johannes 1666 Institutio de usu organi Aristotelici in disciplinis omnibus. Helmaestadii.

Nihusius, Bartholdus 1621 Commentarius logicus novus (...) de enunciationibus et syllogismis modalibus. Helmaestadii.

Nihusius, Bartholdus 1648 Hypodigma, quo diluuntur nonnulla contra Catholicos disputata in Cornelii Martini Tractatu de analysi logica. Coloniae.

Nuchelmans, G. 1980 Late-Scholastic and Humanist Theories of the Proposition. Amsterdam: North-Holland.

Orbellis, Nicolaus: cf. Dorbellus, Nicolaus.

Peter of Spain: cf. Petrus Hispanus.

Petersen, P. 1921 Geschichte der aristotelischen Philosophie im protestantischen Deutschland. Leipzig: Meiner.

Petrus Hispanus 1972 Tractatus, Called Afterwards Summulae Logicales. First Critical Edition from the Manuscripts, ed. L.M. de Rijk. Assen: van Gorcum.

Pozzo, R. 1989a Kant und das Problem einer Einleitung in die Logik. Frankfurt a.M.: Lang.

Pozzo, R. 1989b 'Kornelius Martini: "De natura logicae". Prolegomeni ad un corso di lezioni del 1599', Rivista di storia della filosofia 44, 499-527.

Priscianus 1885-1889 Institutiones grammaticae, ed. M. Hertz. Leipzig: Teubner (rpt. Hildesheim: Olms, 1961). 
Ramus, Petrus 1556 Animadversionum Aristotelicarum libri XX. Parisiis (1st ed. 1543).

Ramus, Petrus 1594 Scholarum dialecticarum seu animadversionum in Organum Aristotelis libri XX, Recens emendati per Johannem Piscatorem. Francofurti.

Rapp, Johannes Henricus 1668 Elementa dialectica ex Commentario logico Domini Johannis Conradi Dannhaweri. Argentorati.

Rijk, L.M. de 1962-1967 Logica Modernorum. Assen: Van Gorcum.

Rijk, L.M. de 1982 'Origins of the Theory of the Properties of Terms', in: Kretzmann, Kenny, and Pinborg 1982, 161-73.

Risse, W. 1964-1970 Die Logik der Neuzeit, Bd. I, 1500-1640, Stuttgart-Bad Cannstatt (1964); Bd. II, 1640-1780, Stuttgart - Bad Cannstatt: Frommann-Holzboog (1970).

Risse, W. 1965-1979 Bibliographia Logica. Hildesheim: Georg Olms.

Roger Bacon 1986 'Summulae dialectices. I-II De termino, de enuntiatione', ed. A. de Libera, Archives d'histoire doctrinale et littéraire du moyen âge 53, 139-289.

Roncaglia, G. 1990 'Historical Remarks on the Theory of Opposition', in: I. Marchlewitz and A. Heinekamp (eds.), Leibniz' Auseinandersetzung mit Vorgängern und Zeitgenossen (Studia Leibnitiana Supplementa XXVII). Stuttgart: Steiner, 173-83.

Roncaglia, G. 1992 'Buone e cattive fantasie: la riflessione sugli enti inesistenti nella logica di Bartholomaeus Keckermann', Metaxù 13, 80-104.

Roncaglia, G. 1996 Palaestra Rationis. Firenze: Olschki.

Roncaglia, G. 1997 'Hoc est corpus meum: Logic and Theology in German "Protestant Scholastics"', in: T. Koistinen and T. Lehtonen (eds.), Philosophical Studies in Religion, Metaphysics, and Ethics. Essays in Honour of Heikki Kirjavainen. Schriften der LutherAgricola Gesellschaft 38, Helsinki: Luther-Agricola-Society, 214-38.

Roncaglia, G. 1998 'L'evoluzione della logica di Melantone', Medioevo 24, 235-65.

Scharfius, Johannes 1632 Institutiones logicae. Wittebergae (1st ed.; also Wittebergae 1656 [5th ed.]).

Scharfius, Johannes 1652 Manuale logicum. Wittebergae.

Scheibler, Christophorus 1665 Opera philosophica. Francofurti.

Schüling, H. 1977 Johann Weiss (1620-1683), Prof. der Ethik und Politik an der Universität Giessen. Gießen: Universitätsbibliothek.

Seifert, A. 1978 Logik zwischen Scholastik und Humanismus. Das Kommentarwerk Johann Ecks. München: Fink.

Stahl, Daniel 1656 Notae et animadversiones in Compendium dialecticae D. Conradi Horneii. Jenae.

Suárez, Franciscus 1597 Metaphysicarum disputationum, in quibus et universa naturalis theologia ordinate traditur, et quaestiones omnes ad duodecim Aristotelis libros pertinentes accurate disputantur, tomus prior et tomus posterior. Salamanticae (1st ed. in Germany: Moguntiae 1600; an anastatic rpt. of the edition Moguntiae 1614 is available: Hildesheim: Olms, 1965).

Tartaretus, Petrus 1581 In summulas Petri Hispani exactae explicationes. Venetiis.

Thoma de Aquino 1976 De propositionibus modalibus, in: Opera Omnia iussu Leonis XIII P. M. edita, vol. XLIII. Roma: Editori di San Tommaso, 419-22.

Titelmannus, Franciscus 1545 Institutionum dialecticarum libri sex. Lugduni.

Toletus, Franciscus 1615-1616 Introductio in universam Aristotelis logicam, in: Opera philosophica. Coloniae Agrippinae (rpt. Hildesheim: Olms, 1985).

Valla, Lorenzo 1962 Opera omnia. Anastatic rpt. of the edition Basileae 1540. Torino: Bottega d'Erasmo.

Valla, Lorenzo 1982 Repastinatio dialectice et philosophie, ed. G. Zippel. Padova: Antenore.

Vives, Johannes Ludovicus 1520 In pseudodialecticos. Selestadii; ed. and Engl. transl. by C. Fantazzi, Leiden: Brill, 1979.

Vives, Johannes Ludovicus 1979 Against the Pseudodialecticians. A Humanist Attack on Medieval Logic, Engl. transl. by R. Guerlac. Dordrecht: Reidel.

Vives, Johannes Ludovicus 1782 Opera omnia. Valentiae. 
Weber, H.E. 1908 Der Einfluss der protestantischen Schulphilosophie auf die orthodoxlutherische Dogmatik. Leipzig: Deichert (rpt. Darmstadt: Wissenschaftliche Buchgesellschaft, 1969).

Weiss, Johannes 1653 Quadriga disputationum logicarum de modalibus enunciationibus et syllogismis. Erfurti.

Wollgast, S. 1988 Philosophie in Deutschland zwischen Reformation und Aufklärung, 15501650. Berlin: Akademie.

Wollgast, S. 1993 Vergessene und Verkannte. Zur Philosophie und Geistesentwicklung in Deutschland zwischen Reformation und Frühaufklärung. Berlin: Akademie.

Wundt, M. 1939 Die deutsche Schulmetaphysik des 17. Jahrhunderts. Tübingen: Mohr.

Zapfius, Gottfridus 1658 Regulae philosophicae ex logicis, metaphysicis ac physicis, diligenter congestae \& compendiose explicatae. Jenae. 